\title{
The Great Retrenchment: International Capital Flows During the Global Financial Crisis
}

\author{
Gian-Maria Milesi-Ferretti \\ International Monetary Fund / CEPR
}

\section{Cédric Tille}

Graduate Institute for International and Development Studies / CEPR

\begin{abstract}
The current crisis saw an unprecedented collapse in international capital flows after years of rising financial globalization. We identify the stylized facts and main drivers of this development. The retrenchment in international capital flows is a highly heterogeneous phenomenon: first across time, being especially dramatic in the wake of the Lehman Brothers' failure, second across types of flows, with banking flows being the hardest hit due to their sensitivity of risk perception, and third across regions, with emerging economies experiencing a shorter-lived retrenchment than developed economies. Our econometric analysis shows that the magnitude of the retrenchment in capital flows across countries is linked to the extent of international financial integration, its specific nature-with countries relying on bank flows being the hardest hit-as well as domestic macroeconomic conditions and their connection to world trade flows.
\end{abstract}

(C) The Authors.

All rights reserved. No part of this paper may be reproduced without the permission of the authors. 


\title{
The Great Retrenchment: International Capital Flows During the Global Financial Crisis ${ }^{1}$
}

\author{
Gian-Maria Milesi-Ferretti \\ International Monetary Fund \\ and CEPR
}

\author{
Cédric Tille \\ Graduate Institute for International \\ and Development Studies, and CEPR
}

First draft: June 1, 2010

This draft: September 15, 2010

\begin{abstract}
The current crisis saw an unprecedented collapse in international capital flows after years of rising financial globalization. We identify the stylized facts and main drivers of this development. The retrenchment in international capital flows is a highly heterogeneous phenomenon: first across time, being especially dramatic in the wake of the Lehman Brothers' failure, second across types of flows, with banking flows being the hardest hit due to their sensitivity of risk perception, and third across regions, with emerging economies experiencing a shorter-lived retrenchment than developed economies. Our econometric analysis shows that the magnitude of the retrenchment in capital flows across countries is linked to the extent of international financial integration, its specific nature-with countries relying on bank flows being the hardest hit-as well as domestic macroeconomic conditions and their connection to world trade flows.
\end{abstract}

\footnotetext{
1 Paper prepared for presentation at the 52 ${ }^{\text {nd }}$ Economic Policy panel, Rome, October 22-23, 2010. Corresponding author : Cédric Tille, Graduate Institute for International and Development Studies, PO Box 136, 1211 Geneva 21, Switzerland, cedric.tille@graduateinstitute.ch. We are grateful to Philippe Martin and three anonymous referees for very useful comments. The views expressed in this paper are those of the authors and do not reflect those of the IMF or IMF policy.
} 


\section{INTRODUCTION}

The global crisis that started in mid-2007 brought an abrupt stop to the sustained rise in international financial integration over the previous decade (figure 1). Global capital flows had steadily increased from less than 7 percent of world GDP in 1998 to over 20 percent in 2007, led in particular by a dramatic expansion of flows to and from advanced economies. These flows simply evaporated during the crisis, which saw large repatriation of capital in many countries. What lies behind this "great retrenchment" in capital flows? Did flows fall evenly across countries and categories of flows? Can we link the intensity of the great retrenchment to financial and macroeconomic characteristics of countries? Is the trend towards rising financial globalization over? The purpose of this paper is to document the collapse in capital flows across a range of developed and emerging economies and to provide answers-some of them necessarily speculative- - to these questions.

We assess the patterns of the retrenchment in international capital flows, and the underlying driving forces. We document that the retrenchment led to an increase in portfolio "home bias", i.e. a reduction of the share of foreign assets in investors' portfolio. Our analysis stresses two broad themes. First, there is a high degree of heterogeneity in the patterns of capital flows, across time, types of flows and countries. Second, international banking flows_-particularly among advanced economies_played a central role both during the pre-crisis globalization and in the crisis itself, a finding in line with earlier work (Bank for International Settlements 2009, Bertaut and Pounder 2009).

Our analysis relies on an extensive dataset of capital flows for 75 countries at a quarterly frequency, with data until the last quarter of 2009. These data are integrated with figures on banks operations through affiliates, and data on domestic financial balance sheets for several countries. To our knowledge this work is the only contribution relying on such an extensive and detailed dataset of balance of payments statistics. Existing studies on international capital flows during the crisis are focused on specific countries, such as the United States (Bertaut and Pounder, 2009) or specific dimensions (such as banking flows-Bank for International Settlements, 2009).

We start by documenting the patterns of capital flows before and during the crisis, and stress how heterogeneous the crisis has been. The first stage of the crisis (from August 2007 to the demise of Lehman Brothers and the AIG bailout) saw a slowdown in capital flows that was concentrated in banking flows among developed economies. In contrast, capital flows to and from emerging markets were generally not affected. The second stage of the crisis coincides with the global panic after the fall of Lehman Brothers (last quarter of 2008 and first quarter of 2009), and was characterized by a broad reversal of capital flows, with investors across the globe liquidating holdings abroad. While the reversal occurred for most types of flows, it was most pronounced in banking flows. The retrenchment was also not confined geographically and emerging markets were hit by a sharp reversal in flows. The third stage of the crisis, starting in the second quarter of 2009, saw a recovery of non-bank capital flows, particularly in Asian and Latin 
American emerging markets. In contrast, flows among developed economies remained well below pre-crisis level, with bank flows still contracting.

Our next step assesses the underlying drivers of capital flows. We argue that the central feature of the collapse in flows during the current crisis has been a shock to risk aversion, as investors' confidence fell abruptly amidst concerns about the quality of financial assets and the solvency of prominent banks. The impact of this shock on a specific country depends on the extent and nature of its international financial linkages, its macroeconomic conditions, and its dependence on world trade. A re-assessment of risk by investors is likely to lead to a more significant pull-back from countries with large net external liabilities, particularly in the form of debt, or those whose external portfolio was more exposed to liquidity risk (for example, countries with large banking positions). Countries that experienced a credit-fueled boom, or where domestic growth and fiscal prospects worsened, were also likely to be more heavily hit. And finally, with the collapse in global trade countries more dependent on exports, particularly of "cyclical" goods such as investment goods and durables, were likely to be most affected.

Our formal assessment of the drivers of the capital flow retrenchment proceeds in two steps. We first contrast countries with the largest retrenchments from countries with the smallest ones. This allows us to consider a broad range of variables, but not to isolate their specific roles. Our second step is thus a cross-section econometric assessment of the drivers of capital flows. We find that the changes in capital flows during the crisis are related to the structure of the countries' external portfolios prior to the crisis. In particular, countries with large pre-crisis external assets and liabilities in the form of debt instruments-where banks play an important role-were hit with a deeper retrenchment of flows during the most acute phase of the crisis. These countries, primarily advanced economies in Europe as well as the United States, still faced flows substantially below their pre-crisis levels during its third stage. The evidence also points to sharper and more persistent declines in capital inflows in countries that entered the crisis with higher net external liabilities, particularly in the form of debt—such as several countries in Central and Eastern Europe.

Looking forward, we conjecture that while the trend to financial globalization will persist, its nature is likely to change. This is because international bank flows are unlikely to regain their pre-crisis magnitude for a variety of reasons, including the fallout from the crisis, ongoing regulatory efforts to rein in large banks, and the fact that the pace of precrisis flows among advanced economies implied a dramatic expansion in cross-border financial balance sheets relative to the size of individual economies. In contrast, financial globalization in emerging markets, which had proceeded at a less dramatic clip, could well prove more robust. In most emerging markets financial systems were less affected by the crisis: no dramatic expansion in banks' cross-border activity had taken place, and there is still ample scope for increased portfolio diversification across borders.

The remainder of the paper is structured as follows. In section II we briefly review the pattern of financial globalization in the years before the crisis, focusing on the role of banking flows. We turn to developments during the crisis in section III, drawing 
the main stylized patterns for industrialized economies and emerging markets. Section IV reviews the literature on the financial crisis and discusses our theoretical a priori about the driving forces. Section V presents an empirical assessment of the drivers of capital. We conclude and discuss the prospects for the future of globalization in section VI.

\section{FINANCIAL GLOBALIZATION BEFORE THE CRISIS}

The decade prior to the crisis saw a boom in international capital flows. Figure 1 shows that the pace at which investors purchased foreign assets picked up substantially in the early 1990's. While the dispersion in world current account balances and net external positions expanded significantly-with some countries running large deficits as other ran large surpluses - the increase in two-way international capital flows and total external assets and liabilities was even more dramatic (see for instance Lane and Milesi-Ferretti 2007, Gerlach et al. 2009). In this section we briefly review the salient features of this process of financial globalization, drawing on several complementary measures. Box 1 provides a brief description of international capital flows and their components, and Appendix A lists the data sources. Our analysis highlights the following key points:

- The increase of cross-border asset holdings reflects a higher share of foreign assets in portfolios, in addition to a generalized rise in the value of assets relative to GDP (financial deepening).

- The increase in international capital flows and cross-border holdings was more pronounced in advanced economies than in emerging markets.

- Growing international financial linkages was accompanied by an increase in the dispersion of current account balances and size of creditor and debtor positions.

- Financial globalization was particularly rapid in the banking sector of advanced economies, including for regulatory arbitrage purposes.

- International banking integration took the form of both cross-border lending and operations through foreign affiliates.

While Figure 1 shows increased international capital flows, it does not allow us to distinguish between the underlying drivers. We are specifically interested in distinguishing between financial deepening (an increase in financial assets with unchanged allocation between domestic and foreign assets) and a reduction in home bias (an increase in the share of financial assets invested in foreign assets).

In the last fifteen years the world has experienced substantial financial deepening. This is illustrated in Figure 2 which presents the value of total financial assets and GDP for several countries in 1997, 2002 and 2007. There is a clear positive trend in all countries, with a noticeable pickup in the pace of deepening since 2002 in several countries such as the United Kingdom and the United States. This process reflects a variety of underlying factors: for example, sharp increases in asset prices, driving up the 
valuation of financial wealth; higher borrowing, backed by higher valuations of nonfinancial assets such as property; and a boom in securitization, which raises the total value of financial instruments outstanding.

If countries allocate overseas a stable fraction of financial assets, the process of financial deepening will naturally lead to a pickup of cross-border capital flows, even if investors do not increase the share of their financial wealth that they want to invest abroad (the "portfolio growth" driver of international capital flows pointed by Kraay and al., 2005). However, financial deepening can offer only a partial account of the rise in international financial flows; the main driver has instead been an increase in the fraction of wealth invested abroad (the "portfolio reallocation" channel of capital flows). This is illustrated in Figure 3, which shows the change in the share of foreign assets in residents' portfolios in recent years. Most countries saw this portfolio share increase by between 1 and 2 percentage points annually during the boom of the 2000's (top panel). A finer look at the data shows that this reflected a deliberate investment choice. The share of foreign assets could indeed increase without any action by investors if asset prices increase faster abroad than in the investor country. This impact of asset price changes on the portfolio shares, depicted by the green bars, was generally moderate, reflecting the fact that asset prices increases fairly evenly across the world. The change in the portfolio share was instead the result of active portfolio management: investors stepped up their purchases of foreign assets relative to their acquisition of domestic assets, with the impact of these purchases on the portfolio share shown by the blue bars.

The increasing appetite of investors for foreign assets also reflects the reduction of formal restrictions on international capital mobility. Figure 4 presents two measures of international capital mobility, namely the index of restrictions on capital mobility from Schindler, 2009 (top panel), and the index of capital mobility from Chinn and Ito, 2008 (bottom panel). Both measures show a decline in de jure restrictions on international capital mobility, with some evidence of a pickup of the shift in the first half of the 1990's, as shown by the unweighted Chinn-Ito index. Other factors imperfectly captured by these indices include financial harmonization legislation within the European Union and the advent of the euro, which spurred international capital mobility within Europe.

Financial globalization led to a polarization of net external positions and flows, with some countries posting large current accounts deficits, while other experienced large surpluses (see for example Blanchard and Milesi-Ferretti, 2010). For instance some economies in the euro area and Central and Eastern Europe experienced a rapid rise of their current account deficits and net external liabilities against a background of easy access to external finance (as shown by a very sharp compression in spreads). Another well-documented aspect of globalization is its concentration in developed economies, where the value of both external assets and liabilities rose at a much faster pace than in emerging markets (Lane and Milesi-Ferretti, 2007, Gerlach et al., 2009). This trend towards was also accompanied by an increase in flows for regulatory arbitrage purposes, 
with international financial centers large and small intermediating sizable shares of crossborder capital movements. ${ }^{2}$

International banking activity played a major role in financial globalization. The Bank of International Settlements compiles detailed data on international bank activity. Its "locational" data cover the assets and liabilities of banks in different countries using the residency concept of the balance of payments (Appendix A presents the data in more details). The value of cross-border bank lending increased substantially since the early 1990's, and particularly on the eve of the crisis (figure 5). The value external assets of banks in the BIS sample rose from 27 percent of world GDP in 1990 to 59 percent in 2007, with 80 percent of this pickup taking place since 2000. International banking activity is also heavily concentrated in developed economies where 80 percent of crossborder banking assets are located. ${ }^{3}$

The rising role of international banking in terms of stocks is also observed in terms of capital flows. Figure 6 presents the split of flows between bank and other flows (red and blue bars respectively). We contrast the situation between outflows and inflows (left and right panels), between advanced economies and emerging markets (top and bottom panels), and through time. Specifically, we distinguish between an early stage of the pre-crisis boom (from 2000 to 2004), a late stage of the boom (until the middle of 2007), the initial stage of the crisis (2007.3 to the eve of the Lehman Brothers collapse), a second "collapse" stage (2008.4-2009.1) and a "recovery" stage through the rest of 2009. We defer a fuller discussion of the three crisis stages to the next section.

International bank lending took a greater prominence in the last stage of the boom. This is especially the case for advanced economies, where the share of bank lending in overall flows was high and rose substantially from a quarter to a third. Emerging markets by contrast show less reliance on bank lending, which represented only 16 percent of gross inflows on the eve of the crisis, and a mere 9 percent of outflows. This pattern reflects the boom in interbank lending activity between advanced financial markets, especially between the United States and Europe as European banks took a substantial presence in the U.S. market, and vice-versa (BIS 2009, 2010), as well as within Europe where cross-border lending took off with the integration of markets in the European Union. Investment in emerging markets by contrast was more reliant on other types of funds, such as FDI and portfolio investment.

The degree of international bank integration is even deeper that what cross-border bank lending indicates. A bank can lend to a foreign borrower either by lending directly

\footnotetext{
${ }^{2}$ Examples include the activities of euro area banks conducted through their affiliates in the United Kingdom; the mutual fund industry in Luxembourg as well as Ireland; hedge funds, international banking activity, and structured finance conducted through the Cayman Islands; and the importance of Ireland for the treasury management operations of large multinational companies.

${ }^{3}$ The situation is similar for liabilities.
} 
across the border, or by doing so through an affiliate in the borrower's country. The first strategy entails a claim by a domestic resident (the bank) on a foreign one (the borrower) and thus enters the balance of payments. The second strategy by contrast entails a loan from the foreign subsidiary to the foreign borrower, and thus does not involve the parent bank. It is thus not recorded in the balance of payments.

The role of affiliates is captured by the Bank for International Settlements' "consolidated" statistics, which combine lending activities cross-border and through affiliates. The latter is in turn split between lending in "local" currency and in other currencies. The data are available on an "immediate borrower" basis and an "ultimate risk" basis (where the latter corrects for the fact that the immediate borrower may benefit from a guarantee from or risk transfer to a third party). While data on an immediate borrower basis covers a longer horizon, it does not isolate cross-border lending. Data on an ultimate risk basis distinguishes between cross-border lending and lending through affiliates, but is only available since 2005 and covers a narrower set of reporting banks (more details are provided in Appendix A).

Lending through affiliates represents a substantial share of international banking activity. Between 1999 and 2007 overall foreign claims of the reporting banks rose from 32 to 62 percent of world GDP (immediate borrower basis, top-left panel of figure 7). ${ }^{4}$ Operations through foreign affiliates represent a large and growing share of this exposure, reaching 44 percent of all claims to developed economies and 52 percent of claims to developing countries on the eve of the crisis (ultimate risk basis, right panels). Table 1 details the growth pattern from December 2005 to December 2007 and shows that both cross-border lending and lending through affiliates grew in line on the eve of the crisis.

\section{INTERNATIONAL CAPITAL FLOWS DURING THE CRISIS}

The long period of buoyant capital flows described in the previous section has come to an abrupt halt as the global financial crisis intensified. This section offers a concise review of the major stylized facts in the crisis, with the following six main points emerging:

- The collapse in capital flows reflects an active reduction of the portfolio share of foreign assets by investors, and not just a portfolio adjustment following a reduction in wealth.

\footnotetext{
${ }^{4}$ We focus on the data since 1999 as a break in the data limits the comparability with 1983-1998 figures. The total amounts of bank claims on a locational basis, consolidated-immediate borrower basis, and consolidated-ultimate risk basis are not comparable because of differences in the number of counties reporting these banking statistics to the BIS. The figure is highest for locational banking statistics (over 40 countries) and lowest for consolidated, ultimate basis statistics.
} 
- The overall decline in capital flows during the crisis was not uniform over time, but went through three distinct phases.

- The decline in capital flows was heterogeneous across countries and regions, with the collapse in capital flows being more temporary for emerging markets.

- The decline in capital flows was heterogeneous across different categories of flows, with international bank lending showing the biggest pullback.

- International banking activity contracted both in terms of cross-border lending and in terms of operations through foreign affiliates, with the magnitude being more pronounced for cross-border operations.

- Prompt and substantial interventions by domestic authorities and international organizations cushioned the macroeconomic impact of the contraction in capital flows. Interventions took the form of swaps between central banks, use of foreign reserves, and lending from multilateral institutions such as the IMF as well as the European Union.

\section{Shift towards domestic assets}

Asset prices have experienced sharp falls during the crisis, a development that has been spread across various types of assets and across countries. To the extent that capital flows are proportional to wealth, such a reduction would naturally have led to a fall in flows. This, however, offers only a partial account of the recent pattern of flows. The crisis has instead been associated with a reduction of the share of assets invested abroad, i.e. an increase in the degree of home bias in investor's portfolios.

The retrenchment towards domestic assets is illustrated in the bottom panel of Figure 3 which shows the change in the share of wealth invested abroad between the end of 2007 and the end of 2009. Most countries experienced a reduction in this portfolio share, or stabilization after years of increases prior to the crisis. This setback in international financial integration does not merely reflects movements in asset prices that could have lowered the portfolio share even without any action by investors (to the extent that asset prices fell by more abroad than domestically). Instead investors have actively repatriated funds invested abroad, with the impact of this retrenchment on the portfolio share shown by the blue bars in Figure $3 .^{5}$

\footnotetext{
${ }^{5}$ The large movements in asset prices and exchange rates during this period imply significant "valuation effects.” For example, the share of foreign assets in total assets increased in the United Kingdom despite substantial capital repatriation by U.K. residents, because of the large depreciation of the pound during this period (foreign assets tend to be denominated in foreign currency, and hence rise in value when the domestic currency depreciates).
} 


\section{A heterogeneous pattern}

While commentators often refer to "the crisis" as a homogeneous global event, a closer look reveals substantial heterogeneity along many dimensions-through time, across countries, and across types of flows. ${ }^{6}$ We document this heterogeneity by focusing on quarterly capital flows since the beginning of 2006, shown in Figure 8 for advanced countries (top panels) and emerging markets (bottom panels). Outflows and inflows are broken down into foreign direct investment (FDI), portfolio investment, bank lending, other flows, reserve accumulation (for outflows only) and net derivatives flows.

We split the sample in four distinct periods. The pre-crisis period runs from early 2006 to the second quarter of 2007. The initial stage of the crisis starts with the outbreak of stress in financial markets in the summer of 2007 and runs until the collapse of Lehman Brothers at the end of the third quarter of 2008. The collapse stage of the crisis runs for two quarters following the fall of Lehman Brothers, while the final recovery stage of the crisis covers the last three quarters of 2009. Vertical dotted lines mark the various periods.

Capital flows remained resilient in the initial stage of the crisis. Focusing on advanced economies, the first signs of stress appear in the second quarter of 2008 (following the turmoil at Bear Stearns) where advanced countries experience a sharp turnaround in gross flows, as investors liquidated foreign holdings and repatriated funds. Flows resumed in the $3^{\text {rd }}$ quarter of 2008 , but things changed abruptly with the collapse of Lehman Brothers, and gross capital flows turned negative for the two subsequent quarters as investors repatriated funds invested overseas. The final stage of the crisis saw a resumption of capital flows, albeit at levels well short of those observed until mid-2008.

The situation was substantially different in emerging markets. Capital flows proved more resilient in the initial phase of the crisis, with only a slowdown during the Bear Stearns episode, as opposed to an actual turnaround. While the collapse stage of the crisis led to a pullback of capital flows to and from emerging markets, this proved shorter-lived than the one for advanced economies. Flows to and from emerging markets already bounced back in the first semester of 2009, and then rapidly rose to levels only moderately below the ones observed before the crisis.

Turning to the composition of flows, international bank lending (red bars) played a dominant role. The retrenchment of flows in advanced economies in the second quarter

\footnotetext{
${ }^{6}$ Lane and Milesi-Ferretti (2010) and Rose and Spiegel (2010) document a sizable heterogeneity in the magnitudes of the recession.
} 
of 2009 was driven by banks. While the pullback in the collapse stage of the crisis is observed across various types of investments, bank flows show by large the largest retrenchment. In addition, banks have continued reducing their cross-border exposure in advanced economies even in the final recovery stage.

Although banking flows also played a major role during the collapse stage in emerging markets, their magnitude remains relatively small compared to other types of flows. Capital inflows to emerging markets took mainly the form of FDI and portfolio investment, which quickly resumed after the collapse. On the outflows side, the accumulation of foreign reserves plays a dominant role. In the collapse stage, emerging countries dipped in their war chest so that the sudden stop in inflows could be met by using reserves instead of having the economy go through a costly shift in the net external balance.

A finer geographical breakdown is given in charts 9 and 10 for advanced countries and emerging markets, respectively. While international bank lending was the main driver of the turnaround of flows in the United States, its role was substantially more pronounced in Europe, and especially in the United Kingdom, reflecting its nature as an international banking center. ${ }^{7}$ The retrenchment of banks from foreign markets has also proved more persistent in Europe than in the United States, where bank outflows and inflows have moderately resumed in the recovery stage.

Flows to and from emerging markets show marked regional differences. Flows have quickly resumed for Latin America and emerging Asia, nearly reaching pre-crisis levels. By contrast, flows to and from emerging Europe-the region hit hardest by the crisis-remain at a very low level in the recovery stage of the crisis.

\section{International banking in the crisis}

International bank lending has retreated markedly during the crisis. The value of cross-border claims fell from 59 percent of world GDP at the end of 2007 to 51 percent in December 2009 (figure 5). This contraction was driven by sharp retrenchment in bank capital flows, an aspect that is concisely shown in figure 6 which averages flows across quarters in each of the three crisis stages. In advanced economies, banks pulled back from their foreign investment during the collapse stage, and have continued doing so in the recovery stage. Non-bank flows by contrast bounced back once the worst stage of the crisis passed. Bank flows to and from emerging markets show a similar pattern, but their share of overall flows being much more limited than in advanced economies, they had only a moderate impact on overall flows.

\footnotetext{
${ }^{7}$ Flows for Switzerland also show a predominance of banking.
} 
As discussed in the previous section, cross-border lending is only one channel through which banks invest in other countries, and the use of local affiliates also plays a large role. While banks pulled back from international activities across the board, they did so to a lesser extent on their affiliates business. The affiliates' share of total claims rose slightly between 2007 and 2009 (by 1 and 1.8 percentage points in claims on developed and developing countries, respectively, on an ultimate risk basis). Table 1 shows that banks' claims on developed economies were reduced primarily through crossborder lending, to a lesser extent through affiliate lending in foreign currency, and even less to affiliate lending in local currency. ${ }^{8}$ While cross-border lending to developing economy remained unchanged, business through affiliates picked up, especially in foreign currencies. ${ }^{9}$

\section{Policy response to the retrenchment}

Policy makers did not remain idle in the face of the collapse of capital flows. Charts 8 and 10 show that emerging countries used their foreign exchange reserves to offset the drying up of capital inflows, thereby limiting the impact on the economy. Central banks also reacted to stress in international bank lending by setting up currency swaps between each other. As the crisis started, it quickly became apparent that European banks needed to raise liquidity in U.S. dollars to fund their (primarily long-term) holdings in the United States (BIS 2009). Prior to the crisis, these banks had relied on short-term dollar funding by issuing commercial paper. However, this channel of financing dried up as money market mutual funds, the main purchasers of commercial paper, curtailed their purchases because of concerns about the banks' assets financed through this channel (which include holdings of mortgage-backed securities) and banks' health more generally. They couldn't obtain funding from the Federal Reserve, and the central bank in their country could only extend loans in local currency. The Federal Reserve lent dollar to the foreign central banks so they could in turn lend them to their own banks. These swaps arrangements were set up in the initial stage of the crisis, reaching over USD 50 billion in the summer 2008 (Board of Governors 2009, Goldberg, Kennedy and Miu 2010). The scale of the swap efforts surged in the wake of the Lehman Brothers failure, reaching US 500 billion at the end of 2008. As markets functioning returns to normal, the swaps were not renewed and had essentially expired by the end of 2009. Goldberg, Kennedy and Miu (2010) find that these arrangements were successful in reducing the strain in dollar funding.

\footnotetext{
${ }^{8}$ The rate of contraction is smaller for affiliate lending in local currency (-2.2 percent, immediate borrower basis) that for overall affiliate lending (-3.7 percent, ultimate risk basis).

${ }^{9}$ The rate of growth is smaller for affiliate lending in local currency (+2.5 percent, immediate borrower basis) that for overall affiliate lending (+3.8 percent, ultimate risk basis).
} 
Multilateral institutions were also actively involved. The European Union extended loans to Eastern European countries to help them offset the stop of funding from foreign investors. Similarly, the IMF set up assistance programs to a broad range of countries. During the collapse stage of the crisis the IMF extended over US\$53 billion in credit in the form of stand-by arrangements (table 2), adding an extra US\$26 billion in the recovery stage. This assistance was put to use with US $\$ 48$ billion being still outstanding at the end of the first quarter of 2010. Additional support was provided through contingent financing in the form of the so-called "Flexible Credit Line."

\section{INTERPRETING THE CRISIS}

The unprecedented global crisis has stimulated a burgeoning literature analyzing its causes and consequences. While many of the papers have focused on financial sector vulnerabilities, a number of others have looked more generally at how the global financial crisis has affected capital flows and economic activity across the globe. With regard to capital flows in advanced economies, Bertaut and Pounder (2009) highlight the important role played by banks in U.S. capital flows during the crisis (including through the activity of European banks vis-à-vis their U.S. affiliates). While the crisis period was generally characterized by flight to safety away from risky securities, the pull-back in portfolio flows was relatively small compared to the large valuation losses due to the large asset price fluctuations. Cetorelli and Goldberg (2010) assess supply shocks to bank lending in the crisis, and find a sizable transmission through cross-border lending, lending through affiliates (use of internal market to direct funds to the parent) and an impact on local banks. They also find that the so-called "Vienna initiative" designed to maintain lines of bank credit to countries in Central and Eastern Europe helped, a result corroborated by the findings of Barba-Navaretti et al. (2010). Another policy response to the crisis was the activation of large swap lines between major central banks. For example, Goldberg, Kennedy, and Miu (2010) document the use of U.S. swap lines, and argue that they were effective at reducing dollar funding pressures and the stress in dollar money markets.

With regard to emerging market economies, authors such as Ghosh et al. (2009) and Blanchard et al. (2010) have underscored how these were affected by an external trade shock, the result of the collapse in domestic demand in advanced economies, and by a "sudden stop" in capital inflows, resulting from substantial deleveraging by financial institutions in the context of a generalized "flight to safety." ${ }^{\prime 10}$ In principle, large holdings

\footnotetext{
${ }^{10}$ It is well-known that emerging-market exposure to U.S. securities backed by sub-prime mortgages was very modest. However, Kamin and Pounder (2010) find that direct exposure to U.S. mortgages does not explain the geographical pattern of the crisis. Instead, what matters is a global risk aversion shock, which affected most severely institutions dependent on short-term funding.
} 
of foreign exchange reserves could have helped cushion the shock, by reducing the need for a large current account adjustment through demand compression in response to declining inflows. Findings on this issue are not fully clear-cut. Obstfeld et al. (2009) fined evidence that countries with large reserves faced less exchange rate pressure. However, Blanchard et al. (2010) do not find evidence that countries with large reserves suffered milder recessions.

Other papers have focused on the factors explaining the cross-country incidence of the crisis (measured in terms of output and demand contraction, exchange rate depreciation, and/or asset price changes). Giannone, Lenza, and Reichlin (2010) stress how the crisis hit more severely countries with weaker credit market regulation. Lane and Milesi-Ferretti (2010) highlight how output and especially demand contractions were sharper in countries with large pre-crisis current account deficits and fast pre-crisis credit growth; Rose and Spiegel (2010), while more skeptical about the ability of pre-crisis variables in explaining crisis outcomes, also find that countries with large current account deficits—as well as more deregulated financial markets—experienced deeper recessions.

Our general reading of the literature points to two key themes: first, the incidence of the crisis is related to the financial excesses (asset price bubbles, dramatic compression of spreads, lax financial regulation etc) and associated macroeconomic imbalances and vulnerabilities (such as large current account deficits) that built up before the crisis; and second, international financial linkages were important in explaining the cross-border transmission of the crisis. In the remainder of this section, we articulate testable hypotheses that we then confront to the data.

Stepping back from the crisis, understanding the determinants of international capital flows has long been a prominent topic for economists. A detailed review of the literature is beyond the scope of this paper, we can point for instance to the role of institutions in shaping the magnitude and form of international capital flows (see for instance Fatih Ekinci et al. 2007), with foreign investors being more willing to take a long-term view in countries with better functioning institutions. However, our focus is not on the level and composition of capital flows, but on their changes during a time of crisis.

Our question is related to the extensive literature on "sudden stops" which considers the causes and consequences of abrupt dry-ups of external funding in emerging markets. The literature finds that both financial integration, in terms of its magnitude and specific form, and domestic conditions play a role. Calvo et al (2008) document that sudden stops are more likely for countries which rely more on short-term funding from banks or portfolio investment than on foreign direct investment. A high reliance of liabilities in foreign currency is also a factor of risk. The magnitude of integration has a non-monotonous effect: countries that are moderately integrated are at greater risk that 
countries that either have only shallow financial links with the rest of the world, or are extensively integrated. Countries with larger public deficits are also more at risk of a sudden stop. Kaminsky (2008) argues that a higher extent of financial integration raises the risk of a sudden stop, even in the absence of domestic problems. Edwards (2004) finds that sudden stops are more likely for countries with large current account deficits, a credit boom, or low foreign reserves.

To understand the behavior of capital flows during the crisis we need to be specific about the nature of the underlying shock. We argue that the collapse of capital flows reflected a large "risk aversion" shock-including aspects of a short-run "liquidity panic" and a more lasting re-assessment of macroeconomic and financial sector risk. The global nature of the shock accounts for the unprecedented degree of international comovements (as documented by Imbs 2010). Accordingly, we start our empirical analysis with an assessment of the link between volatility and global capital flows. Table 2 presents results from a very simple regression of global capital flows (scaled by world GDP) on a measure of "risk", which we proxy with the VIX index of implied volatility on the S\&P 500. We also control for global growth, which can be expected to boost capital flows, and openness to trade (the ratio of world exports plus imports to GDP) as trade in financial assets can be expected to move in step with trade in goods. The signs of the various regression coefficients are as expected: capital flows are higher when risk is low, growth is high, and international integration deeper. The significance of risk shows some sensitivity to the sample. Its significance is weak when we consider the whole sample from 1993 Q1 to 2009 Q4, but increases once we drop the early years of the sample where the extent of financial integration was more limited.

The shock on risk aversion can affect capital flows through three broad channels. First, the re-assessment of risk is likely to lead investors to retrench more from countries with vulnerable conditions. Before the crisis risk appetite was high and all countries were treated benignly. With higher risk aversion we would expect the countries with the weakest fundamentals and higher exposure to financial sector to be most severely affected by a pull-back in capital flows. In this context, it is informative to look not only at the decline in flows during the acute phase of the crisis (the last quarter of 2008 and the first quarter of 2009) but also at the subsequent period (the last 3 quarters of 2009) during which the "liquidity run" was arguably over. In practice, we test whether the capital flow retrenchment was deeper for countries with weak external fundamentals (net external debt; net external liabilities; current account deficits, weak credit market regulation), as well as for those more vulnerable to a liquidity shock (countries with large gross liabilities; countries with larger bank positions). ${ }^{11}$

\footnotetext{
${ }^{11}$ Weak regulation is particularly important if we think that under more laisser-faire the potential for asymmetric information is larger.
} 
The risk aversion shock can also play very differently across types of investment. Arguably, foreign direct investment is more long-term in nature: while it would clearly be affected by a reassessment of medium-term prospects for the economy, it is less vulnerable to concerns about liquidity. Banking flows on the other hand are likely to be most sensitive to the shock. The maturity and liquidity mismatch that characterizes banks leaves them open to bank runs. Banks operated with a thin capital cushion before the crisis, and the losses they faced raised the specter of default, leading investors (including other banks) to pull back as they couldn't assess the banks' solvency with enough confidence. "Other" flows (which include non-bank financial institutions) can also be expected to be substantially affected by the shock. Portfolio investment represents an intermediate case. While it has a shorter focus than FDI, it is not as vulnerable to liquidity and counterparty concerns as bank lending is. In light of this, we would expect retrenchment to be larger for bank flows, less so for portfolio, even less so for FDI-as indeed our analysis of the composition of capital flows in Section III suggests.

Second, countries with domestic vulnerabilities are likely to be seen as more risky by foreign investors. For instance, a credit-fuelled boom can lead to imbalances, such as excessive indebtedness, that are overlooked during the boom period, but lead to a sharp re-assessment once risk appetite is lower. The crisis has also led to a weakening of growth prospects and the fiscal situation in many countries, which can lead investors to view them as riskier than previously and limit their investment in these countries.

Finally, the risk aversion shock led to a sharp contraction in investment and a collapse of global trade, which consists primarily of durable goods and commodities. The sharp recession of the world economy also led to a fall in commodity prices. Countries where manufacturing accounts for a large share of GDP, that rely on commodity exports, or whose trading partners' experience weak growth, are thus more likely to have been adversely affected.

\section{AN ECONOMETRIC ANALYSIS OF THE DRIVERS OF CAPITAL FLOWS}

As discussed in the previous section, we see the crisis as resulting in a dramatic re-assessment by investors of macroeconomic imbalances and financial vulnerabilities in different countries. Accordingly, we investigate more formally whether variables capturing these pre-crisis factors help explain the "sudden stop" in capital flows associated with the post-Lehman stage of the financial crisis, as well as the behavior of flows during the most recent recovery period (the last three quarters of 2009).

For each stage we consider the change in a country's capital flows relative to a the pre-crisis situation: 


$$
\begin{aligned}
& {\text { Change (collapse })_{k, c}} \frac{\text { Annualized capital flows }_{k, c}[2008.4-2009.1]-\text { Annualized capital flows }_{k, c}[2006.1-2007.2]}{G D P_{c}[2007]} \\
& \text { Change }(\text { re cov ery })_{k, c} \\
& =\frac{\text { Annualized capital flows }{ }_{k, c}[2009.2-2009.4]-\text { Annualized capital flows }{ }_{k, c}[2006.1-2007.2]}{G D P_{c}[2007]}
\end{aligned}
$$

where Annualized capital flows ${ }_{k, c}[t 1-t 2]$ is the annualized value of capital flows in category $k$ for country $c$ for the period $t 1$ to $t 2$. We choose to scale the reduction of international capital flows by the country's GDP in order to capture the macroeconomic relevance of capital flows. An alternative would be to scale flows by initial positions, but we do not think this accurately reflects the extent of economic strain. For instance, a country where foreign investors pulled out half of their holdings, but where these holdings account for a small share of GDP, does not suffer much from the collapse in funding. By contrast, a country where investors liquidate a quarter of their holdings, but where these holding account for 100 percent of GDP, experiences a severe cutoff in its funding.

We consider gross capital inflows, gross capital outflows, as well as net capital flows (the difference between inflows and outflows). We also consider gross flows with and without official flows, such as reserve accumulation or support from multilateral organizations. Focusing only on overall flows, we would infer that a country with a large inflow in the form of IMF support faced benign conditions, which clearly would be inaccurate. We present results for different samples (all countries, advanced economies, and emerging markets). ${ }^{12}$ We proceed in two steps. We first contrast the countries where the turnaround of flows was largest with the countries where it was smallest. We then proceed to a formal econometric analysis of the retrenchment of flows in the crosssection of countries. While more rigorous, this second step limits the numbers of variables we can consider without lowering the degrees of freedom to an unacceptably low level.

\section{A. Stylized facts}

We start the analysis by establishing some aggregate "stylized facts" on the relation between the cross-country incidence of the contraction in capital flows and a set

\footnotetext{
${ }^{12}$ Results for an alternative base going until the collapse stage (2006.1 -2008.3, instead of 2006.1-2007.2) are similar, and are available from the authors.
} 
of pre-crisis and crisis variables. Our pre-crisis variables can be regrouped in three broad categories outlined above.

The first group of variables reflects international financial exposure and captures the extent and nature of countries' financial integration with the rest of the world. As highlighted by the narrative of the previous sections, we focus on variables that help capture two of the salient aspects of the global financial turmoil, namely a generalized deleveraging and an increase in home bias, and a global increase in risk aversion. We proxy the former with the size of a country's external balance sheet (the sum of its external assets and liabilities), separating out debt instruments, conceivably more affected by the crisis, from equity instruments, such as FDI and portfolio equity. This is motivated by the fact that contingent assets and liabilities, such as FDI and equity, offer better opportunities of risk sharing than non-contingent assets such as bonds or bank loans. For example, countries with large international banking sectors are likely to be most severely affected by the turmoil in global banking. As for the global increase in risk aversion, this would in principle have a more severe effect on the countries that rely more heavily on foreign saving. We proxy for this through the country's net foreign asset position, and also break it down into equity and debt sub-components. We also split debt holdings between bonds and banks on the one hand and foreign reserves on the other hand, as the latter can be expected to be seen as a source of strength by investors, making them less inclined to cut their funding to the country. Importantly, all "external balance sheet" variables are dated as of end-2005, and therefore prior to the pre-crisis period we consider.

The second set of pre-crisis variables is related to the country's macroeconomic characteristics, both in terms of pre-crisis conditions and in terms of developments during the crisis. The first variable reflecting initial conditions is the growth of GDP in the two years before the crisis (2005-2007), as we can expect investors to be more likely to cut funding to countries with weaker growth. The second is the country's level of development, proxied by the log of per capita GDP. The coefficient on this variable is ambiguous ex ante: while richer countries are likely to be seen as safer investment opportunities, and thus less likely to suffer a capital flow turnaround, they also have been the hardest hit by the contraction in world GDP (Lane and Milesi-Ferretti 2010). Turning to developments during the crisis, the first variable is the change in GDP growth in the country between the crisis and the pre-crisis period. The second is the change in GDP growth in a country's trading partners between the crisis and the pre-crisis period. Countries whose trading partners were more affected by the crisis may experience larger pull-backs of foreign capital (to the extent that countries most severely affected need to repatriate capital) and also reduce their outflows by more (in light of worsened prospects in trading partners). ${ }^{13}$ The third variable is the change in growth projections for the

\footnotetext{
${ }^{13}$ We would ideally want to identify financial trading partners. In practice, there is a strong correlation between the composition of goods and asset trade. Furthermore, establishing the pattern of bilateral financial linkages is complicated by the large role of international financial centers in global asset trade, which obscures the nature of the ultimate borrower or lender in international financial statistics.
} 
country for the period 2009-2012 resulting from the crisis. Pre-crisis growth projections for that period are taken from the April 2007 World Economic Outlook (WEO) and postcrisis projections from the April 2009 WEO. The last two variables capture changes in countries' fiscal prospects as a result of the crisis. Growing fiscal deficits and deteriorating public debt dynamics will reduce the attractiveness of domestic bonds for foreign investors. The fiscal balance variable is defined as the difference in WEO projections for the ratio of the fiscal balance to GDP in 2012 between the April 2009 and the April 2007 WEO. Similarly, the change in projected public debt dynamics is defined as the difference between the April 2009 and April 2007 WEO projections for gross government debt in the year 2012.

The third set of pre-crisis variables are more closely related to international trade, and can have an impact on capital flows both directly but also indirectly, through their effects on a country's export revenues. The first variable is an economy' openness to international trade (the sum of imports and exports over GDP), the most obvious proxy for vulnerability to a global slowdown. The second such variable is the share of manufacturing in GDP. As widely documented (see, for example, Bems et al., 2010) the collapse in world trade in late 2008 has hit hardest countries more reliant on manufacturing activity. The sign on this variable is a priori ambiguous: on the one hand, a higher share of manufacturing may imply a more drastic contraction in export revenues, which could be reflected in lower acquisitions of foreign assets. On the other, it may reduce foreign demand for the country's assets, and hence a reduction in capital inflows. Finally, given the heavy presence of emerging markets in our sample, we also include the commodity trade balance as a ratio of GDP, which captures more generally the magnitude of the country's reliance on primary exports, whose prices fell sharply during the crisis. We generally consider these variables as likely to play a more important role in explaining the change in capital flows for emerging economies than for advanced ones.

Our "stylized facts" are constructed as follows. We divide our country sample into two groups, each comprising around a quarter of the sample: the countries where the decline in capital flows was smallest, and those that suffered the largest declines (the "sudden stop" group). We then compare mean and median values of a set of pre-crisis and crisis variables and indicators between the two samples. The sample excludes a set of international financial centers for which changes in inflows and outflows are very strongly correlated, reflecting these countries' role as international financial intermediaries, and take extreme values. ${ }^{14}$ We also exclude the smallest countries (those with GDP below US\$20 billion).

Table 4 presents the differences in mean and median values of the indicators mentioned above between countries that experienced small declines in inflows and

\footnotetext{
${ }^{14}$ The countries are Belgium, Cyprus, Hong Kong S.A.R., Iceland, Ireland, Lebanon, Luxembourg, Netherlands, Panama, Singapore, Switzerland, and the United Kingdom.
} 
countries that experienced large ones, as well as a t-test for the equality of means. ${ }^{15}$ As discussed above, the decline in inflows is scaled by the country's GDP to capture its macroeconomic relevance. The first line highlights the very large difference in the change in inflows (netting out official flows such as IMF lending) between the two samples. The sudden stop countries faced a reduction of inflows that was larger by about 30 percent of GDP on an annualized basis, relative to the countries that experienced a small reduction. ${ }^{16}$ Also, the second line shows that declines in inflows and outflows generally went together.

Turning to the financial exposure measures, there is strong evidence that countries with larger gross external positions, particularly in debt instruments, suffered more severe declines in inflows. Also, countries whose banks had a more negative net external position, or with an overall external position vis-à-vis BIS banks, suffered more severe declines in inflows, a result consistent with the literature discussion on the central role played by banks in advanced economies in the financial crisis.

Among the variables related to macroeconomic characteristics, we find that declines in capital inflows were larger in countries with higher GDP per capita, a result reminiscent of the findings in Lane and Milesi-Ferretti (2010) and Rose and Spiegel (2010) that output and demand declines were more severe in richer countries. The deterioration of public finances also played a role, as countries larger debts and worsened public deficits faced a larger reversal in flows. Finally, countries with a more acute weakening of growth during the crisis, or worsened growth prospects, also suffered more.

International trade variables also mattered. Countries more open to international trade suffered larger declines in inflows. A weakening of growth in trading partners is also associated with a more pronounced reduction in flows.

Table 5 presents the corresponding results for capital outflows. Overall, results are similar to those presented in Table 4 for inflows: countries with higher GDP per capita, larger gross positions, more negative positions vis-à-vis BIS-reporting banks, and with a worsened fiscal outlook and larger growth declines at home and in trading partners saw a larger compression in total capital outflows. The results also suggest that declines in capital outflows were larger in countries with less regulated credit markets.

While the results from contrasting country samples are broadly consistent with the theoretical priors discussed in the previous sections, we acknowledge that the interpretation of these findings needs to be taken with some caution in light of the strong

\footnotetext{
${ }^{15}$ Specifically, the table show the value of the variables in the countries with small declines in flows , minus the values of countries with large declines.

${ }^{16}$ Specifically, the mean change in inflows net of official was -0.6 percent of GDP in the countries with the smallest decline, and -34.0 percent in the countries with the largest declines, leading to a relative change of inflows by $-0.6-(-34.0)=33.4$ percent of GDP.
} 
correlation between some of the variables in the sample (for example, GDP per capita and all measures of financial openness). We therefore turn to a more formal multivariate regression analysis to separate the influence of various drivers, at the cost of limiting the number of variables we can consider in order to preserve the degrees of freedom. We first contrast capital flows during the collapse stage of the crisis (2008 Q4 - 2009 Q1) relative to the ones prior to the crisis (2006 Q1 - 2007 Q2), and then consider the flows in the recovery stage of the crisis (2009 Q2 - 2009 Q4).

\section{B. Multivariate regression analysis: collapse stage of the crisis}

Our econometric analysis first considers the change in gross capital inflows, before turning to gross outflows, and finally focusing more specifically on banking flows. We present results for the whole sample, as well for advanced economies and emerging markets separately. We adopt a parsimonious specification, particularly so for the advanced economies regressions, in light of the limited number of observations. Our choice of variables is guided by the results presented in Tables 4-5. Relative to the variables considered in those tables, we omit those that refer to the crisis period, with the exception of growth in trading partners. While there seems to be a clear link between the behavior of flows during the crisis and the re-assessment of growth and fiscal prospects in each country, there are thorny endogeneity and causality issues. For example, revisions to public debt dynamics and worsened output prospects reflect factors such as the bursting of bubbles, financial sector losses, as well as changes in global risk aversion and external financing conditions. These problems are arguably less severe for changes in growth in trading partners, with the exception of "large" economies (and hence we exclude this variable from the advanced-country regressions).

Table 6 shows the results when the dependent variable is the change in gross inflows during the sudden stop, relative to the value of inflows before the crisis. Results are reported for total capital inflows (columns 1-3), simply for illustrative purposes, as well as for inflows excluding official lending through IMF programs, other official loans to the government (such as lending by the European Union to Hungary and Latvia), and borrowing by the central bank-for example through swap lines (columns 4-6). As discussed above, the rationale for excluding these flows is that they capture the response of official institutions to the crisis. The dependent variable is the ratio of the change in flows to GDP in percentage points (so a value of -5 indicates a reduction by 5 percent of GDP). Financial exposure variables are measured in percent. The coefficient of -9.08 on gross debt in column 4 then indicates that a country with an extra 10 percent of GDP in gross assets and liabilities in debt instruments saw a larger reduction of inflows by $0.1 \mathrm{x}$ $9.08=0.9$ percent of GDP.

When official flows is included (columns 1-3), we find evidence of a sharper decline in inflows in advanced economies with larger gross debt positions and in emerging markets with a high ratio of private credit to GDP, but no link between the country's net debt position and the decline in inflows. Once we exclude official flows (column 4-onwards), results show clearly that the sudden stop in capital inflows was more severe for countries with a larger size of gross positions in debt instruments (a 
negative coefficient on the "gross debt assets + liabilities" variable) and, for emerging markets, larger net liabilities in debt instruments (a positive coefficient on the "net debt assets" variable), which is in line with the priors discussed in section IV. ${ }^{17}$ The effects are statistically and economically significant: for example, other things being equal, an emerging market country with a pre-crisis net position in debt instruments (securities, loans, deposits etc) stronger by 10 percentage points of GDP experienced a reduction in flows about 3 percentage points of GDP smaller. It is also interesting to note that higher pre-crisis reserve holdings are not associated with a smaller decline in inflows-if anything, the opposite is true (even though the coefficient is not precisely estimated). This result can be explained by the fact that countries used foreign exchange reserves to limit the need for drastic corrections in net flows - the reduction in reserves allowed other sectors to access foreign exchange and reduce external liabilities, implying a reduction in capital inflows. ${ }^{18}$ For the emerging market sample, we also find that the decline in inflows was larger in countries with faster pre-crisis growth, higher GDP per capita, higher pre-crisis private credit. The coefficient on growth in trading partners during the crisis period has the expected positive sign (faster growth in trading partners associated with a smaller decline in inflows) but the coefficient is not precisely estimated. We find little evidence of a systematic impact of pre-crisis growth, level of development, and trade-related variables on the extent of the decline in capital inflows.

We present an analogous set of results for capital outflows in Table 7, with columns (1)-(3) reporting results using the change in total capital outflows as the dependent variable and columns (4)-(6) presenting results for the change in capital outflows excluding official flows (such as reserve accumulation and changes in monetary authorities' claims vis-à-vis nonresidents). The specification is slightly different relative to the one for capital inflows. In particular, given the presence of some oil exporters in our sample and the dramatic decline in oil prices during the crisis period, we include among the explanatory variables a dummy for oil exporters. Our results show some differences between advanced economies and emerging markets. In particular, for advanced economies there is strong evidence of a larger decline in outflows when precrisis gross cross-border debt positions were large (the coefficient on the "gross debt assets + liabilities" variable is more negative and statistically significant for the advanced economies' sample), which drives the significance of the gross debt variable in the whole sample regression. For emerging markets the evidence suggests a much sharper decline in outflows in oil-exporting countries, but no robust relation between the size of capital outflows and other explanatory variables.

\footnotetext{
${ }^{17}$ The "Net debt assets" variable is the country's net position in debt instruments (securities, loans, deposits etc), with a positive value indicating that it is a net creditor vis-à-vis the rest of the world in these instruments. The positive coefficients in table 4 thus indicate, for example, that countries that were net creditors experienced a smaller decline in inflows compared to net debtors.

${ }^{18}$ Remember that capital inflows are net acquisitions by nonresidents of claims on domestic residents. Hence if a domestic firm repays a foreign loan the transaction is recorded as a negative capital inflow.
} 
In Table 8 we focus more specifically on gross and net banking inflows, relating them to gross and net banking positions as well as to a parsimonious set of pre-crisis variables (GDP per capita, output growth, oil dummy) and, for emerging markets, the change in growth rate for trading partners during the crisis period relative to the pre-crisis period. The results suggest that emerging economies with larger gross bank debt positions and more negative net bank debt positions suffered a sharper decline in gross and net banking inflows. Also, for emerging markets faster pre-crisis growth is associated with a sharper decline in gross and net inflows. For advanced economies, for which twoway banking flows are dominant, we find a sharper contraction in total flows for countries with larger gross bank positions. The pattern for net banking flows is similar to the one for emerging markets, but the estimates are not statistically significant. Estimates relying on a more complete advanced economies sample that includes financial centers (results available from the authors) point to a positive and statistically significant relation between the net bank position at end-2005 and the change in net banking inflows during the crisis period, again in line with our priors.

\section{Multivariate regression analysis: recovery stage of the crisis}

We turn now to examining the patterns of flows during the last 3 quarters of 2009, again relative to the pre-crisis period. Considering this period after the height of the crisis allows us to establish whether some of the patterns we identified in the previous subsection are primarily related to the global panic following the events of September 2008, or whether they persist during the recovery stage.

Table 9 presents the results for the decline in capital inflows, and is constructed along similar lines as table 6 . Results are broadly consistent to those we obtained for the crisis period - in particular, the decline in inflows is larger for countries with larger gross debt positions and slower growth in trading partners, but there is no statistically significant correlation between pre-crisis net debt positions.

Table 10 presents the results for capital outflows. Again, results are similar to those obtained for the crisis period, with a sharper contraction in outflows for countries with larger gross debt positions. Not surprisingly, in light of the recovery in oil prices, the size and statistical significance of the oil dummy coefficient is reduced relative to the crisis-period regressions. It is also interesting to contrast the size of the coefficient on the initial stock of foreign exchange reserves in the emerging market regressions in Tables 7 and 10. The coefficient on reserves is negative in the collapse stage (albeit imprecisely estimated) consistent with central banks in high-reserve countries selling reserves to offset the impact of a decline in capital inflows. The coefficient however becomes positive and small in the recovery stage, as many emerging markets rebuilt their stock of reserves as capital inflows resumed.

Table 11 presents the result for banking flows. Results are similar to the ones for the collapse stage: in particular, emerging markets with higher net external bank debt pre- 
crisis still show larger gross and net declines in bank inflows. The evidence also suggests sharper declines in gross and net bank inflows in oil exporters, a result consistent with the recovery in oil export prices relative to the crisis period reducing the need for external finance.

Overall, our simple econometric analysis finds evidence for an impact of international financial exposure on the behavior of international capital flows. Countries with large holdings of debt and bank positions saw a larger contraction in capital inflows during the crisis, as well as in the immediate post-crisis period. Also, countries with a stronger net external position in debt instruments being less affected by the turnaround of capital flows. Macroeconomic conditions and the exposure to international trade also play a role, especially for emerging economies. The decline in inflows has been larger in countries with higher GDP per capita and faster pre-crisis growth rates, as well as those whose trading partners suffered steeper declines in growth rates relative to the pre-crisis period. Trends in oil prices are important in explaining capital outflows from emerging markets.

\section{Conclusions AND Prospects for FinANCiAL GLOBALIZATION}

Our analysis of the patterns of capital flows during the financial crisis stresses common elements, as well as several dimensions of heterogeneity. We document how the crisis evolved in distinct stages, with capital flows collapsing only in the wake of the Lehman Brothers' bankruptcy. Emerging and developed economies fared very differently, with many emerging markets experiencing only a temporary, albeit sharp, disruption in international capital flows. The diversity of experiences across countries can be linked to the size of gross and net external exposures, and particularly to the reliance on debt instruments and the importance of bank cross-border activity.

With regard to the questions raised in the introduction, the evidence points to the following answers:

What lies behind the retrenchment” in capital flows? Primarily the dramatic contraction in cross-border banking activity and global deleveraging, including by nonbank financial institutions. The contraction in flows during the first year of the crisis was concentrated among banking flows. These flows also played a prominent role during the collapse stage.

Did flows fall evenly across countries and categories of flows? No. Emerging markets were essentially spared until the collapse stage. Even then, some recovered in short order after the crisis, whereas flows in other regions still remain well below the precrisis levels. The contraction in flows was concentrated in banking flows, with smaller declines in portfolio investment and especially FDI.

Can we link the intensity of the retrenchment to financial and macroeconomic characteristics of countries? Yes for financial characteristics: countries with high degrees of financial integration through debt and banking were more affected, and countries with 
large net liabilities in debt instruments suffered sharper declines in capital inflows. While it is more difficult to pinpoint a strong systematic relation between the magnitude of the capital flow retrenchment and other pre-crisis macroeconomic conditions, the evidence suggests that the decline in capital inflows was linked to the extent of downward revisions to the growth and fiscal outlook, as well as to growth declines in trading partners. For emerging markets, the evidence also suggests a link between trade and capital flows operating through the impact of commodity prices on export revenues.

Is the trend towards rising financial globalization over? Of course we do not know whether the trends we have highlighted will gradually unwind as the world economy recovers, or whether the crisis of 2008-09 will mark a watershed in the evolution of international capital flows. Still, relying on the main features of growing cross-border capital flows discussed in Section II we provide some (necessarily speculative) views on whether the impact of the crisis on those underlying factors is likely to be long-lasting.

1. "Financial deepening" within countries, reflected in sizable increases in financial balance sheets (both domestic and cross-border). The process may well suffer a setback in advanced economies for several reasons: a potentially reduced use of securitization; limits on large and complex financial institutions; the impact of declines in the valuation of nonfinancial assets, such as real estate, on debt. In the main advanced economies, one of the legacies of the crisis is a significant expansion in public sector balance sheets, and an important question for the dynamics of cross-border flows will be the role played by nonresident investors in financing of this expansion. The past decade saw an unprecedented increase in foreign ownership of domestic debt instruments, associated first with the massive global increase in foreign exchange reserves by emerging markets, which are primarily invested in advanced economies' government paper; second with the advent of the euro, which triggered a sharp increase in demand for government paper from other euro area countries; and third with the overall trend towards international financial integration. It is an open question whether this trend will be resilient to the significant deterioration in fiscal prospects for advanced economies. The scope for financial deepening is clearly stronger in emerging markets, but could well take place only gradually, particularly given governments' concerns about 'financial excesses' following the global crisis.

2. Rising international portfolio diversification, reflecting a decline in home bias. The scope for portfolio diversification remains significant, particularly for emerging markets. On their asset side, the process may be associated with a decline in the role of reserve accumulation and an increase in alternative types of flows. On their liability side, demand for emerging market assets is likely to increase after the financial crisis, in light of the resilience of these countries to the global turmoil on financial markets, their growth prospects, and strong macroeconomic fundamentals. However, an open question is whether changes in financial regulation in response to the crisis could be associated with increasing home bias, particularly for advanced economies. 
3. Increased cross-border activity by international financial institutions (including for regulatory arbitrage purposes). In the years before the crisis, international banking played a major role in the process. Banks in advanced economies were also at the core of the turmoil since 2007. First in the initial stage of the crisis, where capital flow disruption were essentially limited to banking flows among developed economies, but also in the collapse stage as banking flows show the sharpest retrenchment across a broad range of countries. Bank flows have also remained lackluster in the final stage of the crisis, with continuing retrenchments in many regions. The ongoing efforts aimed at reforming banking and financial regulation could also hinder a return to large banking flows. The crisis has clearly demonstrated the risks posed by large global financial institutions that can be too big to rescue. One of the main themes of reform is then to limit the size of banks, which would likely limit their international operations as well. In addition, a big question mark relates to the future scope for cross-border financial flows driven by regulatory and tax arbitrage considerations, which played a very significant role in the expansion of global flows during the pre-crisis period. On the other hand, cross-border activity by financial institutions domiciled in emerging markets, which is so far relatively limited in comparison to advanced economies, may well increase. These banks have weathered the global financial crisis well, also in light of their limited external exposures, and have a strong domestic deposit base. The likelihood and size of their cross-border expansion is of course dependent on the evolution of their domestic regulatory regimes.

4. Increased financial integration within the euro area following EMU, and within the European Union more generally. The process has already run its course to a significant extent, and the sovereign debt market crisis of early 2010 suggests a decline in substitutability between assets issued by different euro area governments and financial institutions. At a minimum, we think that this factor is unlikely to provide the same boost to international capital flows as during the past decade. 


\section{References}

Alfaro, Laura, Sebnem Kalemli-Ozcan, and Selin Sayek, 2009. "FDI, Productivity and Financial Development”, World Economy 32(1), pages 111-135

Bank for International Settlements, 2009a. $79^{\text {th }}$ Annual Report, Basel.

Bank for International Settlements, 2009b. Quarterly Review, March.

Bank for International Settlements, 2009c. Quarterly Review, June.

Bank for International Settlements, 2009d. Quarterly Review, September.

Barba Navaretti, Giorgio, Giacomo Calzolari, Alberto Franco Pozzolo, Micol Levi (2010). "Multinational Banking in Europe: Financial Stability and Regulatory Implications - Lessons from the Financial Crisis”, mimeo, University of Milan.

Bertaut, Carol, and Laurie Pounder, 2009. "The Financial Crisis and U.S. Cross-Border Financial Flows.” Federal Reserve Bulletin 93, pp- A147-A167.

Board of Governors of the Federal Reserve, 2009. "Credit and liquidity programs and the balance sheet: Central banks liquidity swaps”, online explanatory note. http://www.federalreserve.gov/monetarypolicy/bst liquidityswaps.htm

Calvo, Guillermo, Alejandro Izquierdo, and Luis-Fernando Mejia, 2008. "Systemic sudden stops: the relevance of balance-sheet effects and financial integration”, NBER working paper 14026.

Cetorelli, Nicola and Linda Goldberg, 2010, "Global Banks and International Shock Transmission: Evidence from the Crisis,” Federal Reserve Bank of New York Staff Report 446, May (forthcoming, IMF Economic Review).

Chinn, Menzie, and Hiro Ito, 2008. "A New Measure of Financial Openness," Journal of Comparative Policy Analysis 10(3), pages 307-320.

Chudik, Alexander and Marcel Fratzscher, 2010, "The Role of Liquidity, Risk and Economic Activity in the Global Transmission of the Financial Crisis,” mimeo, European Central Bank, July.

Curcuru, Stephanie (2007). “U.S. Cross-Border Derivatives Data: A User's Guide.” Federal Reserve Bulletin 93. 
Edwards, Sebastian, 2004. "Financial openness, sudden stops and current account reversals”, NBER working paper 10277.

Fatih Ekinci, Mehmet, Sebnem Kalemli-Ozcan, and Bent Sorensen, 2007, Financial Integration within EU Countries: The Role of Institutions, Confidence and Trust, NBER International Seminar on Macroeconomics.

Ghosh, Atish, Marcos Chamon, Christopher Crowe, Jun Kim, and Jonathan Ostry, 2009, "Coping with the crisis: policy options for emerging market countries," IMF Staff Position Note 09/08, April.

Giannone, Domenico, Michele Lenza, and Lucrezia Reichlin, 2010, "Market Freedom and the Global Recession,” ECARES working paper 2010-020, May (forthcoming, IMF Economic Review).

Goldberg, Linda, Craig Kennedy and Jason Miu, 2010. “Central Bank Dollar Swap Lines and Overseas Dollar Funding Costs “, NBER working paper 15763.

Kamin, Steve, and Laurie Pounder, 2010. "How did a domestic housing slump turn into a global financial crisis?”, Board of Governors, International Finance Discussion Paper 994.

Imbs, Jean, 2010. "The first global recession in decades", IMF economic review, forthcoming.

Kaminsky, Graciela, 2008. "Crises and sudden stops: evidence from international bond and syndicated loan markets”, NBER working paper 14249.

Kraay, Aart, Norman Loayza, Luis Servén, and Jaume Ventura, 2005. "Country Portfolios," Journal of the European Economic Association, vol. 3(4), pages 914-945.

Lane, Philip, and Gian Maria Milesi-Ferretti (2007). "A Global Perspective on External Positions.” In Richard H. Clarida, ed., G7 Current Account Imbalances: Sustainability and Adjustment. NBER Conference Report. Chicago: University of Chicago Press.

Lane, Philip, and Gian Maria Milesi-Ferretti (2010a). "The cross country incidence of the global crisis”, IMF Economic Review, forthcoming.

Lane, Philip, and Gian Maria Milesi-Ferretti (2010b). "Cross-Border Investment in Small International Financial Centers,” IMF Working Paper 10/38, February. 
Obstfeld, Maurice, Jay Shambaugh, and Alan Taylor, 2009, “ Financial instability, reserves, and central bank swap lines in the panic of 2008,” NBER Working Paper 14826, March.

Rose, Andrew K. and Mark Spiegel, 2010, "Cross-Country Causes and Consequences of the Crisis: An Update,” mimeo.

Schindler, Martin, 2009. "Measuring Financial Integration: A New Data Set," IMF Staff Papers 56(1), pages 222-238. 


\section{Box 1. Concepts and measures of international financial integration}

International capital flows are based on the residency criterion of the balance of payments, and cover transactions where one of the counterparty is a resident of the country (say the euro area) and the other a resident of the rest of the world. Capital outflows denote net purchases by domestic residents of financial instruments issued by nonresidents, while capital inflows denote net purchases by foreign residents of domestic financial instruments. The difference between capital inflows and outflows (the financial account balance) is corresponds to the current account balance (up to a statistical discrepancy).

International capital flows (acquisition of claims) and the corresponding stocks (value of outstanding claims) are broken down into several categories.

- $\quad$ Foreign direct investment represents a controlling claim in a company (a stake of at least 10 percent), either by the setting up of foreign operations or the acquisition of a company abroad by a domestic one.

- $\quad$ Portfolio investment covers holdings of bonds and equity that do not lead to a controlling stake.

- “Other investment” includes a broad residual array of transactions/holdings between residents and nonresidents, such as loans and deposits, trade credits etc. Within this category, we separate out those transactions or holdings in which the domestic counterpart is a bank.

- $\quad$ Reserves denote assets held abroad by the country's government or monetary authority, primarily in the form of liquid assets (this category only exists for outflows).

- $\quad$ Financial derivatives flows are payments and receipts between residents and nonresidents related to new or outstanding derivatives positions. In our analysis of capital flows, we classify the value of net transactions in financial derivatives on the inflows side of the balance of payments.

While cross-border holdings represent the most prominent form of international financial integration, there are other channels of financial exposure. In particular, the banks of a country can be exposed to the economic conditions of another either by lending directly (banking capital flows) or by having affiliates in the foreign country that lend using locally-raised funds.

Finally, cross-border financial holdings offer a picture of wealth held abroad. Their value can be compared with that of residents' domestic assets, i.e. the claim on a resident on another one, to assess the extent to which a country's residents are internationally diversified. 


\section{APPENDIX A: data sources}

\section{$\underline{\text { International capital flows }}$}

Capital flows are taken from the International Monetary Fund's Balance of Payments Statistics database ('standard presentation'). Capital flows are measured at a quarterly frequency. Our sample consists of 75 economies, which account for 95 percent of the world's GDP. 28 are developed economies: United States, United Kingdom, Euro Area (further broken in 16 members: Austria, Belgium, Cyprus, Finland, France, Germany, Greece, Ireland, Italy, Luxembourg, Malta, Netherlands, Portugal, Slovakia, Slovenia, Spain), Japan, Canada, Australia, New Zealand, Denmark, Iceland, Norway, Sweden and Switzerland. 47 economies are emerging markets: 13 in Latin America (Argentina, Brazil, Chile, Colombia, Costa Rica, Ecuador, El Salvador, Guatemala, Mexico, Paraguay, Peru, Uruguay, Venezuela), 11 in Asia (China, Hong Kong S.A.R., India, Indonesia, Korea, Malaysia, Philippines, Singapore, Taiwan province of China, Thailand, Vietnam), 15 in Europe (Albania, Belarus, Bulgaria, Croatia, Czech Republic, Estonia, Hungary, Latvia, Lithuania, Poland, Romania, Russia, Serbia, Turkey, Ukraine) and 8 in other regions (Armenia, Azerbaijan, Israel, Kazakhstan, Lebanon, Morocco, Pakistan, South Africa). For China, quarterly flows are calculating by interpolating semiannual data from national sources, using quarterly data on the trade balance, foreign exchange reserves, and banking flows from the BIS. For Taiwan province of China the balance of payments data is obtained from the Central Bank's website. The only countries of global relevance for international capital flows that are not included in our sample are large Middle-Eastern oil exporters, such as Saudi Arabia and the United Arab Emirates, for which quarterly balance of payments data are not available.

As the crisis saw a substantial use of swap lines between central banks and support from multilateral institutions, we break the "other" category further between central banks swap lines, IMF lending, and official lending. While the balance of payments statistics do not include a specific line for the swaps between central banks, we estimates them as the sum of the loans, deposit and other assets by the monetary authority, both for gross outflows and inflows. The gross outflows under these categories are distinct from exchange rate reserves. Our estimates are consistent with data from the major central banks (United States, Switzerland, Euro area). The balance of payments data for the United Kingdom do not indicate the capital outflows and inflows linked to the monetary authorities. Our estimate for the gross swap inflows are then built based on the changes in the "other liabilities" category reported on the Bank of England's balance sheet.

On the capital inflows side, IMF lending (use of Fund credits and loans) is recorded as a liability of monetary authorities, while official lending from other sources (for example, EU loans to Hungary and Latvia) are recorded as other investment liabilities of the government. 
Another adjustment to the data is related to the issuance of IMF Special Drawing Rights (SDR) to member countries in the $3^{\text {rd }}$ quarter of 2009 , which totaled over $\$ 250$ billion. This allocation was recorded as an increase in foreign exchange reserves in that quarter, offset by a corresponding increase in the liabilities of monetary authorities. Our 2009Q3 data on total capital inflows and outflows - as well as on reserve flows and flows related to monetary authorities' transactions_-net out the impact of the SDR allocation.

\section{International bank claims}

The Bank for International Settlements publishes data on international banks' exposure under two complementary concepts. Data under the locational concept cover the international assets and liabilities of all banks located in a country. These banks include banks headquartered in the country, as well as affiliates of foreign banks. For instance, the Czech subsidiary of a German bank is counted as a Czech entity. These data correspond to the residency concept of the balance of payments.

The consolidated basis considers the international exposure of a country's banks through cross border lending, as well as lending through the affiliates (local claims under the BIS definition). Under that basis the Czech subsidiary of a German bank is counted as a German entity. The consolidated data encompass three types of lending: cross-border lending (a), lending through affiliates in another currency than the local one (b), and lending through affiliates in the local currency (c).

The data are available on two bases: the "immediate borrower" basis which considers the entity that the bank lends to, and the "ultimate risk" basis corrects for the fact that the borrower could itself be part of a corporate group active in many countries. The immediate borrower basis includes a longer horizon (since 1983) but only indicates lending in foreign currency, either cross-border or through an affiliate (a and b above, international claims under the BIS definition), and lending through affiliates in local currency (c). The ultimate risk basis by contrast distinguishes cross-border lending (a) from lending through affiliates (b and c), but is only available since 2005 and covers a more narrow set of reporting banks.

\section{Foreign and domestic holdings}

We contrast international and domestic holdings using data from financial accounts / flow of funds statistics. The data present the value of an economy's financial assets and liabilities by sector (households, non-financial businesses, government, financial sector, and rest of the world). The assets of the rest of the world correspond to the liabilities of the country to foreign investors. Similarly, the liabilities of the rest of the world represent assets held abroad by the country's residents. The value of financial assets held by residents is the sum of financial assets held by domestic sectors. The share invested by residents abroad is the ratio of rest of the world liabilities to assets held by domestic residents. 
Our analysis uses annual data for 22 countries (Austria, Belgium, Canada, Czech Republic, Denmark, Finland, France, Germany, Greece, Hungary, Ireland, Italy, Japan, Korea, Netherlands, Norway, Poland, Portugal, Spain, Sweden, United Kingdom, and United States). The data are taken from the OECD and Eurostat. The sample starts at different dates for different countries, but all are covered from 2003 onwards. The data cover the value of assets at the end of 2007 for all 22 countries, but the values at the end of 2009 are available only for 13 countries (Belgium, Denmark, Finland, Germany, Greece, Hungary, Ireland, Norway, Portugal, Spain, Sweden, United Kingdom, and United States).

\section{Appendix B. Definition of variables}

GDP per capita: GDP per capita in current U.S. dollars, 2007. Source: IMF, World Economic Outlook (WEO) database.

GDP growth 2005-2007: average GDP growth during the period 2005-2007. Source: IMF, WEO database.

Financial openness: Sum of external assets and liabilities over GDP for end-2005. Source: Lane and Milesi-Ferretti, External Wealth of Nations Mark II (EWN II) database.

Gross Debt: sum of debt assets (including reserves) and liabilities divided by GDP, end2005. Source: Lane and Milesi-Ferretti, EWN II database.

Gross Debt (banks): sum of bank external assets and liabilities in the form of debt instruments divided by GDP, end-2005. Source: authors' calculations based on IMF, Balance of Payments Statistics and BIS, locational banking statistics.

Gross Equity: sum of portfolio equity and FDI assets and liabilities divided by GDP, end-2005. Source: Lane and Milesi-Ferretti, EWN II database.

Net Debt: difference between debt assets (including reserves) and debt liabilities, divided by GDP, end-2005. Source: Lane and Milesi-Ferretti, EWN II database.

Net debt (banks): difference between bank external assets and liabilities in the form of debt instruments divided by GDP, end-2005. Source: authors' calculations based on IMF, Balance of Payments Statistics and BIS, locational banking statistics.

Net Equity: difference between the sum of portfolio equity and FDI assets and portfolio equity and FDI liabilities divided by GDP, 2005. Source: Lane and Milesi-Ferretti, EWN II database. 
NFA/GDP: Net foreign asset position divided by GDP, end-2005. Source: Lane and Milesi-Ferretti, EWN II database.

Net position vis-à-vis BIS banks: net position vis-à-vis BIS-reporting banks divided by GDP, December 2005. Source: BIS, locational banking statistics.

Foreign exchange reserves: Source: IMF, International Financial Statistics.

Trade openness: Sum of imports and exports of goods and services over GDP. Source: IMF, WEO.

Share of manufacturing output: Share of manufacturing output in total output. Source: United Nations.

Commodity trade balance: Balance of trade in commodities divided by GDP. Source: authors' calculations based on United Nations data.

Private Credit / GDP and change in private credit/GDP: World Bank Financial Structure database (Beck, Demirgüç-Kunt and Levine (2000, 2009) and updates in Lane and Milesi-Ferretti (2010).

Change in growth: difference in GDP growth between the 2008-09 average and the 2005-2007 average. Source: IMF, WEO database.

Change in growth in trading partners: difference in GDP growth in trading partners between the 2008-09 average and the 2005-2007 average. Source: IMF, WEO database.

Change in public debt projections: difference in the projected ratio of gross government debt to GDP for 2012 between the April 2009 April 2009 WEO and the April 2007 WEO. Source: IMF, WEO database.

Change in fiscal balance projections: difference in the projected ratio of the fiscal balance to GDP for 2012 between the April 2009 WEO and the April 2007 WEO. Source: IMF, WEO database.

Change in growth projections: difference in the projected average growth rate for the period 2009-2012 between the April 2009 April 2009 WEO and the April 2007 WEO. Source: IMF, WEO database.

Credit market restriction index: Economic Freedom of the World index of credit market regulation (Giannone et al. 2010). 
Table 1: Foreign claims of BIS-reporting banks, consolidated basis Annualized percentage change

\begin{tabular}{|c|c|c|c|c|c|c|c|}
\hline \multicolumn{4}{|c|}{ Immediate borrower basis } & \multicolumn{4}{|c|}{ Ultimate risk basis } \\
\hline & $\begin{array}{l}\text { Dec 2005- } \\
\text { Dec } 2007\end{array}$ & $\begin{array}{l}\text { Dec 2007- } \\
\text { Dec } 2009\end{array}$ & $\begin{array}{c}\text { Value Dec } \\
2009, \% \\
\text { world GDP }\end{array}$ & & $\begin{array}{l}\text { Dec 2005- } \\
\text { Dec } 2007\end{array}$ & $\begin{array}{l}\text { Dec 2007- } \\
\text { Dec } 2009\end{array}$ & $\begin{array}{c}\text { Value Dec } \\
\text { 2009, \% } \\
\text { world GDP }\end{array}$ \\
\hline \multicolumn{4}{|c|}{ Claims on all countries } & \multicolumn{4}{|c|}{ Claims on all countries } \\
\hline \multirow{3}{*}{$\begin{array}{l}\text { Total foreign claims } \\
\text { Cross-border } \\
\text { Affiliates, foreign curr. } \\
\text { Affiliates, local curr. }\end{array}$} & 26.2 & -5.6 & \multirow[t]{3}{*}{52.6} & \multirow{3}{*}{$\begin{array}{l}\text { Total foreign claims } \\
\text { Cross-border } \\
\text { Affiliates, foreign curr. } \\
\text { Affiliates, local curr. }\end{array}$} & 27.0 & -5.6 & \multirow[t]{3}{*}{43.3} \\
\hline & 26.6 & \multirow{2}{*}{-7.2} & & & 26.8 & -7.1 & \\
\hline & 25.5 & & & & 27.3 & -3.7 & \\
\hline \multicolumn{4}{|c|}{ Claims on developed countries } & \multicolumn{4}{|c|}{ Claims on developed countries } \\
\hline \multirow{3}{*}{$\begin{array}{l}\text { Total foreign claims } \\
\text { Cross-border } \\
\text { Affiliates, foreign curr. } \\
\text { Affiliates, local curr. }\end{array}$} & 25.2 & -7.0 & \multirow[t]{3}{*}{41.2} & \multirow{3}{*}{$\begin{array}{l}\text { Total foreign claims } \\
\text { Cross-border } \\
\text { Affiliates, foreign curr. } \\
\text { Affiliates, local curr. }\end{array}$} & 24.9 & -7.2 & \multirow[t]{3}{*}{33.6} \\
\hline & 25.4 & \multirow{2}{*}{-8.5} & & & 24.0 & -8.0 & \\
\hline & 24.7 & & & & 26.2 & -6.2 & \\
\hline \multicolumn{4}{|c|}{ Claims on developing countries } & \multicolumn{4}{|c|}{ Claims on developing countries } \\
\hline \multirow{3}{*}{$\begin{array}{l}\text { Total foreign claims } \\
\text { Cross-border } \\
\text { Affiliates, foreign curr. } \\
\text { Affiliates, local curr. }\end{array}$} & 35.9 & 2.0 & \multirow[t]{3}{*}{7.6} & \multirow{3}{*}{$\begin{array}{l}\text { Total foreign claims } \\
\text { Cross-border } \\
\text { Affiliates, foreign curr. } \\
\text { Affiliates, local curr. }\end{array}$} & 40.2 & 2.2 & \multirow[t]{3}{*}{6.9} \\
\hline & 37.5 & 1.6 & & & 45.4 & 0.2 & \\
\hline & 34.0 & 2.5 & & & 36.3 & 3.8 & \\
\hline
\end{tabular}

Source: BIS consolidated banking statistics. International bank exposure (foreign claims) takes the form of A) cross-border claims, B) claims through local affiliates in foreign currency and C) claims through local affiliates in local currency.

The data on the "immediate borrower" basis split "international claims" (A+B and C) but do not include cross-border claims separately.

The data on the "ultimate risk" basis distinguish between cross border claims and claims through local affiliates in all currencies (B+C), but start only in 2005 and cover a narrower set of reporting banks. 
Table 2. IMF assistance under Stand-by-arrangements USD billions

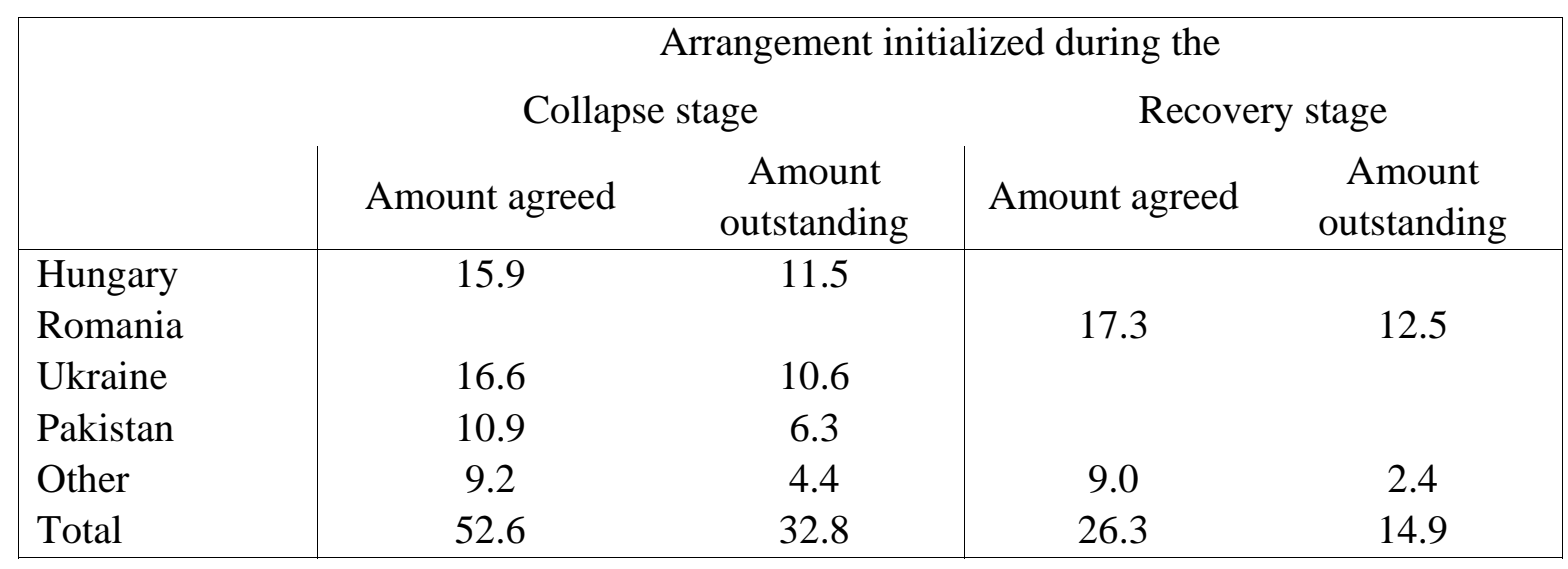

Note: the amount outstanding are as of March 31, 2010. Source: IMF. 
Table 3. Drivers of world capital flows.

Dependent variables: world capital flows / world GDP, adjusted for seasonal dummies.

\begin{tabular}{|lccc|}
\hline & $\begin{array}{c}\text { Long } \\
\text { sample }\end{array}$ & $\begin{array}{c}\text { Medium } \\
\text { sample }\end{array}$ & $\begin{array}{c}\text { Short } \\
\text { sample }\end{array}$ \\
VIX index on the S\&P500 & -0.0029 & $-0.0046^{* *}$ & $-0.0059^{* *}$ \\
& {$[0.0018]$} & {$[0.0022]$} & {$[0.0023]$} \\
World GDP growth & $3.134^{* * *}$ & $2.724^{* * *}$ & $2.434^{* * *}$ \\
& {$[0.607]$} & {$[0.735]$} & {$[0.730]$} \\
World trade openness & $1.645^{* * *}$ & $1.460^{* * *}$ & $1.512^{* * *}$ \\
& {$[0.514]$} & {$[0.540]$} & {$[0.532]$} \\
Trend & & & \\
& -0.001 & -0.002 & $-0.003 * *$ \\
& {$[0.001]$} & {$[0.002]$} & {$[0.002]$} \\
Constant & & & \\
& $-0.54 * * *$ & $-0.40^{* *}$ & -0.29 \\
& {$[0.15]$} & {$[0.18]$} & {$[0.18]$} \\
Sample & & & \\
Observations & $1993 \mathrm{Q} 1$ & $1996 \mathrm{Q} 1$ & $1998 \mathrm{Q} 1$ \\
R-squared & $-2009 \mathrm{Q} 4$ & $-2009 \mathrm{Q} 4$ & $-2009 \mathrm{Q} 4$ \\
& 68 & 56 & 48 \\
& 0.64 & 0.66 & 0.72 \\
\hline
\end{tabular}

Note: World trade openness is defined as world exports and imports over GDP. Robust standard errors in parenthesis. $* * * \mathrm{p}<0.01,{ }^{* *} \mathrm{p}<0.05,{ }^{*} \mathrm{p}<0.1$ 
Table 4. Decline in gross capital inflows excluding official flows (in percent of GDP): Mean and median differences in variables between countries not suffering a sudden stop and countries suffering a sudden stop

\begin{tabular}{|c|c|c|c|}
\hline & $\begin{array}{l}\text { Difference } \\
\text { in means }\end{array}$ & $\begin{array}{l}\text { Difference } \\
\text { in medians }\end{array}$ & $\begin{array}{c}\text { t-statistic } \\
\text { for } \\
\text { difference } \\
\text { in means }\end{array}$ \\
\hline \multicolumn{4}{|l|}{ Change in capital flows } \\
\hline Change in inflows net of official flows (pct of GDP) & 33.4 & 30.9 & 10.1 \\
\hline Change in outflows (pct of GDP) & 17.5 & 21.8 & 4.7 \\
\hline \multicolumn{4}{|c|}{ International financial exposure } \\
\hline Financial openness/GDP & $-108 \%$ & $-78 \%$ & -2.9 \\
\hline Gross debt/GDP & $-73 \%$ & $-56 \%$ & -3.4 \\
\hline Gross debt (banks)/GDP & $-68 \%$ & $-69 \%$ & -4.4 \\
\hline Gross equity/GDP & $-35 \%$ & $-42 \%$ & -2.0 \\
\hline FX reserves/GDP & $-2 \%$ & $-1 \%$ & -0.4 \\
\hline NFA/GDP & $6 \%$ & $-3 \%$ & 0.6 \\
\hline Net debt position excl reserves/GDP & $7 \%$ & $5 \%$ & 1.0 \\
\hline Net bank debt position/GDP & $13 \%$ & $16 \%$ & 2.3 \\
\hline Net equity position/GDP & $0 \%$ & $5 \%$ & 0.0 \\
\hline Net position vis-à-vis BIS banks/GDP & $16 \%$ & $14 \%$ & 4.4 \\
\hline \multicolumn{4}{|c|}{ Domestic macroeconomic characteristics } \\
\hline GDP per capita & $-14,207$ & $-16,915$ & -2.6 \\
\hline GDP growth 2005-2007 & 0.4 & 1.1 & 0.4 \\
\hline Change in private credit to GDP ratio & -0.1 & -0.1 & -1.2 \\
\hline Change in growth (2008-09 - 2005-07) & 3.0 & 0.8 & 1.7 \\
\hline Change in public debt projections & $-16 \%$ & $-20 \%$ & -2.8 \\
\hline Change in fiscal balance projections & $2.7 \%$ & $2.7 \%$ & 2.4 \\
\hline Change in growth projections & $1 \%$ & $0.4 \%$ & 2.0 \\
\hline Credit market restriction index & -0.5 & -0.4 & -1.4 \\
\hline \multicolumn{4}{|l|}{ Impact of international trade } \\
\hline Change in growth trading partners (2008-09 - 2005-07) & 0.9 & 0.6 & 2.1 \\
\hline Share of manufacturing output & $-1.4 \%$ & $-1.9 \%$ & -0.7 \\
\hline Commodity trade balance & $3.8 \%$ & $3.7 \%$ & 0.9 \\
\hline Trade openness & $-36 \%$ & $-25 \%$ & -2.4 \\
\hline
\end{tabular}

Note: the table shows the difference of variables between the countries in the bottom quartile of capital inflows decline (i.e. the smallest decline) and the countries in the top quartile. 
Table 5. Decline in gross capital outflows (in percent of GDP):

Mean and median differences in variables between countries without a large reduction in outflows and countries with a large reduction in outflows

\begin{tabular}{|c|c|c|c|}
\hline & $\begin{array}{l}\text { Difference } \\
\text { in means }\end{array}$ & $\begin{array}{l}\text { Difference } \\
\text { in medians }\end{array}$ & $\begin{array}{l}\text { t-statistic } \\
\text { for } \\
\text { difference } \\
\text { in means }\end{array}$ \\
\hline \multicolumn{4}{|l|}{ Change in capital flows } \\
\hline Change in outflows (pct of GDP) & 29.5 & 30.4 & 12.1 \\
\hline Change in inflows net of official flows (pct of GDP) & 20.8 & 20.0 & 4.5 \\
\hline \multicolumn{4}{|c|}{ International financial exposure } \\
\hline Financial openness/GDP & -145.9 & -143.3 & -4.4 \\
\hline Gross debt/GDP & $-88 \%$ & $-94 \%$ & -3.8 \\
\hline Gross debt (banks)/GDP & $-71 \%$ & $-85 \%$ & -4.6 \\
\hline Gross equity/GDP & $-56 \%$ & $-58 \%$ & -4.1 \\
\hline FX reserves/GDP & $1 \%$ & $0 \%$ & 0.2 \\
\hline NFA/GDP & $-14 \%$ & $-13 \%$ & -1.2 \\
\hline Net debt position excl reserves/GDP & $-1 \%$ & $5 \%$ & -0.1 \\
\hline Net bank debt position/GDP & $10 \%$ & $13 \%$ & 1.7 \\
\hline Net equity position/GDP & $-14 \%$ & $-5 \%$ & -1.6 \\
\hline Net position vis-à-vis BIS banks/GDP & $15 \%$ & $15 \%$ & 2.5 \\
\hline \multicolumn{4}{|c|}{ Domestic macroeconomic characteristics } \\
\hline GDP per capita & $-20,160$ & $-16,035$ & -3.3 \\
\hline GDP growth 2005-2007 & 0.5 & 1.3 & 0.5 \\
\hline Change in private credit to GDP ratio & -0.1 & -0.1 & -2.7 \\
\hline Change in growth (2008-09 - 2005-07) & 2.6 & 0.5 & 1.6 \\
\hline Change in public debt projection & $-15 \%$ & $-15 \%$ & -2.8 \\
\hline Change in fiscal balance projections & $3.1 \%$ & $3.2 \%$ & 3.6 \\
\hline Change in growth projections & $1 \%$ & $0.8 \%$ & 2.1 \\
\hline Credit market restriction index & -0.7 & -0.9 & -2.5 \\
\hline \multicolumn{4}{|l|}{$\underline{\text { Impact of international trade }}$} \\
\hline Change in growth in trading partners (2008-09 - 2005-07) & 1.0 & 0.5 & 2.5 \\
\hline Share of manufacturing output & $3.4 \%$ & $4.7 \%$ & 1.5 \\
\hline Commodity trade balance & $-4.3 \%$ & $-1.0 \%$ & -1.1 \\
\hline Trade openness & $-23 \%$ & $-31 \%$ & -1.4 \\
\hline
\end{tabular}

Note: the table shows the difference of variables between the countries in the bottom quartile of capital outflows decline (i.e. the smallest decline) and the countries in the top quartile. 
Table 6. Collapse stage, gross capital inflows.

Dependent variables: annualized change in gross inflows between 2006Q1-2007Q2 and 2008Q42009Q1, scaled by 2007 GDP.

\begin{tabular}{|c|c|c|c|c|c|c|}
\hline & & Total inflov & & Excl & Iding offici & flows \\
\hline & All & Emerging & Advanced & All & Emerging & Advanced \\
\hline $\begin{array}{l}\text { Net debt position excl. } \\
\text { reserves (ratio of GDP) }\end{array}$ & $\begin{array}{l}-2.39 \\
{[8.75]}\end{array}$ & $\begin{array}{c}12.48 \\
{[15.78]}\end{array}$ & $\begin{array}{l}-11.74 \\
{[16.34]}\end{array}$ & $\begin{array}{c}17.22 * * \\
{[7.65]}\end{array}$ & $\begin{array}{l}33.57 * * \\
{[15.48]}\end{array}$ & $\begin{array}{c}10.83 \\
{[12.44]}\end{array}$ \\
\hline Gross debt position / GDP & $\begin{array}{l}-7.49 * \\
{[3.86]}\end{array}$ & $\begin{array}{l}-3.37 \\
{[5.01]}\end{array}$ & $\begin{array}{c}-10.68^{* *} \\
{[4.80]}\end{array}$ & $\begin{array}{c}-9.08 * * \\
{[3.43]}\end{array}$ & $\begin{array}{c}-8.28 * * \\
{[3.34]}\end{array}$ & $\begin{array}{c}-11.59 * * \\
{[4.72]}\end{array}$ \\
\hline GDP growth 2005-07 & $\begin{array}{c}-0.46 \\
{[0.85]}\end{array}$ & $\begin{array}{c}-0.81 \\
{[1.10]}\end{array}$ & $\begin{array}{l}-1.68 \\
{[4.31]}\end{array}$ & $\begin{array}{l}-1.65^{*} \\
{[0.82]}\end{array}$ & $\begin{array}{c}-1.90 * * \\
{[0.85]}\end{array}$ & $\begin{array}{l}-1.03 \\
{[3.21]}\end{array}$ \\
\hline Private credit / GDP, 2007 & $\begin{array}{c}-5.83 \\
{[3.96]}\end{array}$ & $\begin{array}{c}-13.11^{* * *} \\
{[4.15]}\end{array}$ & & $\begin{array}{c}-2.36 \\
{[3.88]}\end{array}$ & $\begin{array}{c}-10.44 * * \\
{[3.84]}\end{array}$ & \\
\hline Log GDP per capita & $\begin{array}{c}-2.09 \\
{[1.88]}\end{array}$ & $\begin{array}{c}-2.72 \\
{[2.39]}\end{array}$ & & $\begin{array}{l}-3.06 * \\
{[1.64]}\end{array}$ & $\begin{array}{c}-5.18 * * \\
{[2.13]}\end{array}$ & \\
\hline Growth in trading partners & $\begin{array}{l}2.89 * \\
{[1.72]}\end{array}$ & $\begin{array}{c}2.59 \\
{[2.11]}\end{array}$ & & $\begin{array}{c}2.59 \\
{[1.55]}\end{array}$ & $\begin{array}{c}1.75 \\
{[1.61]}\end{array}$ & \\
\hline Constant & $\begin{array}{c}35.14^{* *} \\
{[16.89]}\end{array}$ & $\begin{array}{l}44.57 * * \\
{[21.74]}\end{array}$ & $\begin{array}{c}-0.23 \\
{[13.80]}\end{array}$ & $\begin{array}{c}49.65 * * * \\
{[15.71]}\end{array}$ & $\begin{array}{c}71.65^{* * *} \\
{[19.72]}\end{array}$ & $\begin{array}{c}5.28 \\
{[10.84]}\end{array}$ \\
\hline $\begin{array}{l}\text { Observations } \\
\text { R-squared }\end{array}$ & $\begin{array}{c}57 \\
0.40\end{array}$ & $\begin{array}{c}40 \\
0.49\end{array}$ & $\begin{array}{c}17 \\
0.25\end{array}$ & $\begin{array}{c}57 \\
0.49\end{array}$ & $\begin{array}{c}40 \\
0.64\end{array}$ & $\begin{array}{c}17 \\
0.32\end{array}$ \\
\hline
\end{tabular}

Note: Robust standard errors in parenthesis. ${ }^{* * *} \mathrm{p}<0.01$, ** $\mathrm{p}<0.05$, ${ }^{*} \mathrm{p}<0.1$ 
Table 7. Collapse stage, gross capital outflows.

Dependent variables: annualized change in gross outflows between 2006Q1-2007Q2 and 2008Q42009Q1, scaled by 2007 GDP.

\begin{tabular}{|c|c|c|c|c|c|c|}
\hline & \multicolumn{3}{|c|}{ Total outflows } & \multicolumn{3}{|c|}{ Excluding official flows } \\
\hline & All & Emerging & Advanced & All & Emerging & Advanced \\
\hline Net debt position (excl & 0.35 & 9.5 & -12.35 & 13.01 & 29.56 & -6.45 \\
\hline reserves)/GDP & {$[8.21]$} & [12.91] & [11.14] & [13.01] & [23.35] & {$[12.26]$} \\
\hline Reserves / GDP & $\begin{array}{c}1.38 \\
{[13.82]}\end{array}$ & $\begin{array}{c}-23.2 \\
{[17.36]}\end{array}$ & & $\begin{array}{c}-8.14 \\
{[28.22]}\end{array}$ & $\begin{array}{c}-48.63 \\
{[31.85]}\end{array}$ & \\
\hline Gross debt position / GDP & $\begin{array}{c}-8.59 * * \\
{[3.41]}\end{array}$ & $\begin{array}{c}2.75 \\
{[5.67]}\end{array}$ & $\begin{array}{c}-12.48^{* * * *} \\
{[3.31]}\end{array}$ & $\begin{array}{c}-9.01 * * \\
{[4.19]}\end{array}$ & $\begin{array}{c}6.88 \\
{[5.95]}\end{array}$ & $\begin{array}{c}-12.13^{* *} \\
{[4.20]}\end{array}$ \\
\hline GDP growth 2005-07 & $\begin{array}{l}-0.34 \\
{[0.73]}\end{array}$ & $\begin{array}{l}-0.67 \\
{[0.97]}\end{array}$ & $\begin{array}{l}-3.61 \\
{[2.55]}\end{array}$ & $\begin{array}{c}-1.23 \\
{[1.17]}\end{array}$ & $\begin{array}{l}-2.11 \\
{[1.78]}\end{array}$ & $\begin{array}{l}-3.32 \\
{[2.76]}\end{array}$ \\
\hline oil exporter dummy & $\begin{array}{c}-11.74^{* * *} \\
{[3.67]}\end{array}$ & $\begin{array}{c}-16.08^{* * *} \\
{[4.65]}\end{array}$ & & $\begin{array}{c}-22.79 * * * \\
{[7.47]}\end{array}$ & $\begin{array}{c}-30.85 * * * \\
{[8.05]}\end{array}$ & \\
\hline log GDP per capita & $\begin{array}{l}-1.96 \\
{[1.40]}\end{array}$ & $\begin{array}{l}-2.15 \\
{[1.90]}\end{array}$ & & $\begin{array}{c}-0.77 \\
{[2.07]}\end{array}$ & $\begin{array}{l}-1.25 \\
{[3.29]}\end{array}$ & \\
\hline Growth in trading partners & $\begin{array}{c}1.91 \\
{[1.16]}\end{array}$ & $\begin{array}{c}2.38 \\
{[1.47]}\end{array}$ & & $\begin{array}{c}2.62 \\
{[1.76]}\end{array}$ & $\begin{array}{c}3.03 \\
{[2.41]}\end{array}$ & \\
\hline Constant & $\begin{array}{l}25.38 * \\
{[14.06]}\end{array}$ & $\begin{array}{c}29.51 \\
{[19.12]}\end{array}$ & $\begin{array}{c}7.29 \\
{[9.19]}\end{array}$ & $\begin{array}{c}24.55 \\
{[21.18]}\end{array}$ & $\begin{array}{c}35.88 \\
{[31.51]}\end{array}$ & $\begin{array}{c}7.38 \\
{[10.10]}\end{array}$ \\
\hline Observations & 57 & 40 & 17 & 57 & 40 & 17 \\
\hline R-squared & 0.46 & 0.48 & 0.47 & 0.33 & 0.46 & 0.32 \\
\hline
\end{tabular}

Note: Robust standard errors in parenthesis. *** $\mathrm{p}<0.01$, ** $\mathrm{p}<0.05$, ${ }^{*} \mathrm{p}<0.1$ 
Table 8. Collapse stage, bank flows.

Dependent variables: annualized change in flows between 2006Q1-2007Q2 and 2008Q4-2009Q1, scaled by 2007 GDP.

\begin{tabular}{|lccccccc}
\hline & \multicolumn{3}{c}{ Total inflows } & \multicolumn{3}{c}{ Net inflows } \\
& All & Emerging & Advanced & All & Emerging & Advanced \\
Net bank position / GDP & 12.37 & $53.19^{* *}$ & 0.73 & 15.1 & 42.35 & 7.3 \\
& {$[11.26]$} & {$[21.67]$} & {$[10.81]$} & {$[11.46]$} & {$[25.29]$} & {$[13.99]$} \\
Gross bank position/GDP & $-16.08^{* * *}$ & -12.06 & $-15.80^{* * *}$ & $-6.30^{*}$ & $-12.27^{* *}$ & -4.16 \\
& {$[3.70]$} & {$[8.71]$} & {$[3.43]$} & {$[3.17]$} & {$[5.87]$} & {$[3.64]$} \\
GDP growth 2005-07 & $-1.15^{*}$ & $-1.41^{* *}$ & 0.41 & $-1.69 * *$ & $-1.79^{*}$ & -0.66 \\
& {$[0.60]$} & {$[0.65]$} & {$[2.50]$} & {$[0.78]$} & {$[0.88]$} & {$[2.20]$} \\
Log GDP per capita & 0.06 & -0.06 & & -0.16 & 0.24 & \\
& {$[1.02]$} & {$[1.48]$} & & {$[1.38]$} & {$[1.82]$} & \\
oil & -3.56 & -5.21 & & -3.62 & -4.09 & \\
Growth in trading partners & {$[3.14]$} & {$[3.09]$} & & {$[2.96]$} & {$[3.23]$} & \\
& 1.32 & -0.29 & & 0.98 & -0.81 & \\
Constant & {$[1.23]$} & {$[1.12]$} & & {$[1.33]$} & {$[1.39]$} & \\
& 12.62 & 8.04 & 0.3 & 15.58 & 6.11 & 3.05 \\
Observations & {$[10.22]$} & {$[12.48]$} & {$[7.86]$} & {$[12.89]$} & {$[14.39]$} & {$[7.71]$} \\
R-squared & & & & & & 16 \\
& 53 & 37 & 16 & 53 & 37 & 0.08 \\
\hline
\end{tabular}

Note: Robust standard errors in parenthesis. ${ }^{* * *} \mathrm{p}<0.01,{ }^{* *} \mathrm{p}<0.05,{ }^{*} \mathrm{p}<0.1$ 
Table 9. Recovery stage, gross capital inflows.

Dependent variables: annualized change in gross inflows between 2006Q1-2007Q2 and 2009Q22009Q4, scaled by 2007 GDP.

\begin{tabular}{|c|c|c|c|c|c|c|}
\hline & \multicolumn{3}{|c|}{ Total inflows } & \multicolumn{3}{|c|}{ Excluding official flows } \\
\hline & All & Emerging & Advanced & All & Emerging & Advanced \\
\hline $\begin{array}{l}\text { Net debt position excl. } \\
\text { reserves (ratio of GDP) }\end{array}$ & $\begin{array}{l}-1.85 \\
{[9.87]}\end{array}$ & $\begin{array}{c}19.56 \\
{[14.84]}\end{array}$ & $\begin{array}{c}-20.3 \\
{[16.41]}\end{array}$ & $\begin{array}{c}4.78 \\
{[7.01]}\end{array}$ & $\begin{array}{c}19.08 \\
{[14.83]}\end{array}$ & $\begin{array}{l}-4.79 \\
{[7.89]}\end{array}$ \\
\hline Gross debt position / GDP & $\begin{array}{l}-7.33^{*} \\
{[4.11]}\end{array}$ & $\begin{array}{l}-5.00 \\
{[5.58]}\end{array}$ & $\begin{array}{c}-12.02 * * \\
{[4.95]}\end{array}$ & $\begin{array}{c}-7.38 * * \\
{[3.19]}\end{array}$ & $\begin{array}{l}-8.59 * \\
{[4.28]}\end{array}$ & $\begin{array}{c}-10.75 * * \\
{[4.27]}\end{array}$ \\
\hline GDP growth 2005-07 & $\begin{array}{c}0.55 \\
{[0.93]}\end{array}$ & $\begin{array}{c}0.17 \\
{[1.10]}\end{array}$ & $\begin{array}{l}-1.35 \\
{[2.86]}\end{array}$ & $\begin{array}{c}0.4 \\
{[0.91]}\end{array}$ & $\begin{array}{c}0.33 \\
{[1.07]}\end{array}$ & $\begin{array}{c}0.44 \\
{[2.50]}\end{array}$ \\
\hline Private credit / GDP, 2007 & $\begin{array}{c}0.2 \\
{[3.63]}\end{array}$ & $\begin{array}{l}-3.34 \\
{[3.83]}\end{array}$ & & $\begin{array}{c}0.95 \\
{[3.40]}\end{array}$ & $\begin{array}{c}0.02 \\
{[3.87]}\end{array}$ & \\
\hline Log GDP per capita & $\begin{array}{l}-0.96 \\
{[1.86]}\end{array}$ & $\begin{array}{l}-1.94 \\
{[2.18]}\end{array}$ & & $\begin{array}{c}0.39 \\
{[1.56]}\end{array}$ & $\begin{array}{l}-1.55 \\
{[2.17]}\end{array}$ & \\
\hline Growth in trading partners & $\begin{array}{l}3.91^{* *} \\
{[1.63]}\end{array}$ & $\begin{array}{c}2.99 \\
{[1.85]}\end{array}$ & & $\begin{array}{c}4.83 * * * \\
{[1.51]}\end{array}$ & $\begin{array}{l}4.14^{* *} \\
{[1.59]}\end{array}$ & \\
\hline Constant & $\begin{array}{c}24.75 \\
{[15.03]}\end{array}$ & $\begin{array}{l}34.62 * \\
{[18.37]}\end{array}$ & $\begin{array}{c}7.11 \\
{[12.61]}\end{array}$ & $\begin{array}{c}17.61 \\
{[13.89]}\end{array}$ & $\begin{array}{l}34.90 * \\
{[18.17]}\end{array}$ & $\begin{array}{c}6.33 \\
{[9.92]}\end{array}$ \\
\hline $\begin{array}{l}\text { Observations } \\
\text { R-squared }\end{array}$ & $\begin{array}{c}57 \\
0.33\end{array}$ & $\begin{array}{c}40 \\
0.36\end{array}$ & $\begin{array}{c}17 \\
0.41\end{array}$ & $\begin{array}{c}57 \\
0.38\end{array}$ & $\begin{array}{c}40 \\
0.46\end{array}$ & $\begin{array}{c}17 \\
0.45\end{array}$ \\
\hline
\end{tabular}

Note: Robust standard errors in parenthesis. ${ }^{* * *} \mathrm{p}<0.01,{ }^{* *} \mathrm{p}<0.05$, ${ }^{*} \mathrm{p}<0.1$ 
Table 10. Recovery stage, gross capital outflows.

Dependent variables: annualized change in gross outflows between 2006Q1-2007Q2 and 2009Q22009Q4, scaled by 2007 GDP.

\begin{tabular}{|lcccccc|}
\hline & \multicolumn{3}{c}{ Total outflows } & \multicolumn{3}{c}{ Excluding official flows } \\
& All & Emerging & Advanced & All & Emerging & Advanced \\
Net debt position (excl & -7.24 & 5.34 & -22.54 & -5.69 & 13.52 & -26.75 \\
reserves)/GDP & {$[6.81]$} & {$[11.02]$} & {$[13.22]$} & {$[8.13]$} & {$[13.42]$} & {$[15.84]$} \\
Reserves / GDP & 13.64 & 2.03 & & 23.4 & 2.96 & \\
& {$[10.58]$} & {$[8.19]$} & & {$[16.06]$} & {$[12.66]$} & \\
Gross debt position / GDP & $-8.13^{*}$ & -0.92 & $-12.13^{* *}$ & $-8.37 *$ & 0.36 & $-10.70^{*}$ \\
& {$[4.05]$} & {$[3.91]$} & {$[4.94]$} & {$[4.46]$} & {$[4.07]$} & {$[5.46]$} \\
GDP growth 2005-07 & 0.79 & 0.34 & -1.63 & 0.54 & -0.45 & -1.28 \\
& {$[0.81]$} & {$[0.80]$} & {$[2.32]$} & {$[1.00]$} & {$[1.10]$} & {$[2.52]$} \\
oil exporter dummy & $-9.67 *$ & $-7.44 *$ & & $-13.35 *$ & -10.42 & \\
& {$[5.27]$} & {$[4.07]$} & & {$[7.96]$} & {$[6.53]$} & \\
log GDP per capita & 1.5 & 1.47 & & 3.16 & 3.83 & \\
& {$[1.66]$} & {$[2.08]$} & & {$[2.54]$} & {$[3.38]$} & \\
Growth in trading partners & 0.73 & 0.54 & & 0.4 & 0.07 & \\
& {$[1.02]$} & {$[0.89]$} & & {$[1.33]$} & {$[1.35]$} & \\
Constant & -14.51 & -13.71 & 7.85 & -31.1 & -31.53 & 3.52 \\
& {$[14.37]$} & {$[16.94]$} & {$[11.91]$} & {$[23.56]$} & {$[28.49]$} & {$[14.09]$} \\
Observations & 5.36 & 40 & 17 & 57 & 40 & 17 \\
R-squared & 0.36 & 0.11 & 0.52 & 0.26 & 0.20 & 0.44 \\
\hline
\end{tabular}

Note: Robust standard errors in parenthesis. *** $\mathrm{p}<0.01$, ** $\mathrm{p}<0.05$, ${ }^{*} \mathrm{p}<0.1$ 
Table 11. Recovery stage, bank capital inflows.

Dependent variables: annualized change in flows between 2006Q1-2007Q2 and 2009Q2-2009Q4, scaled by 2007 GDP.

\begin{tabular}{|lcccccc|}
\hline & \multicolumn{3}{c}{ Total inflows } & \multicolumn{3}{c}{ Net inflows } \\
& All & Emerging & Advanced & All & Emerging & Advanced \\
Net bank position / GDP & $15.52^{*}$ & $37.07^{* *}$ & 8.99 & 11.66 & $28.73^{* *}$ & 3.03 \\
& {$[8.78]$} & {$[14.90]$} & {$[10.40]$} & {$[9.28]$} & {$[12.78]$} & {$[13.25]$} \\
Gross bank position/GDP & $-8.68^{* * *}$ & -7.36 & $-8.26^{* *}$ & -0.63 & -7.85 & 1.72 \\
& {$[2.69]$} & {$[5.09]$} & {$[2.85]$} & {$[3.53]$} & {$[4.96]$} & {$[4.33]$} \\
GDP growth 2005-07 & 0 & -0.03 & 0.77 & 0.05 & 0.11 & -0.51 \\
& {$[0.41]$} & {$[0.37]$} & {$[2.95]$} & {$[0.43]$} & {$[0.35]$} & {$[2.93]$} \\
Log GDP per capita & 1.33 & 1.17 & & 1.26 & $1.82 *$ & \\
& {$[0.86]$} & {$[0.81]$} & & {$[0.96]$} & {$[0.91]$} & \\
Oil & $-5.88^{*}$ & $-7.09 * *$ & & -2.64 & $-5.57 * * *$ & \\
Growth in trading partners & {$[3.23]$} & {$[3.38]$} & & {$[2.97]$} & {$[1.92]$} & \\
& $2.28^{* * *}$ & 1.61 & & $3.21 * * *$ & $2.23 * *$ & \\
Constant & {$[0.79]$} & {$[0.98]$} & & {$[1.00]$} & {$[1.08]$} & \\
& -0.72 & -2.02 & -0.91 & 2.58 & -4.98 & -0.98 \\
Observations & {$[8.43]$} & {$[7.57]$} & {$[7.51]$} & {$[9.85]$} & {$[8.87]$} & {$[8.28]$} \\
R-squared & & & & & & 16 \\
& 53 & 37 & 16 & 53 & 37 & 0.02 \\
\hline
\end{tabular}

Note: Robust standard errors in parenthesis. ${ }^{* * *} \mathrm{p}<0.01$, ** $\mathrm{p}<0.05$, ${ }^{*} \mathrm{p}<0.1$ 
Figure 1. Global Capital Flows, 1975-2009

Percent of world GDP

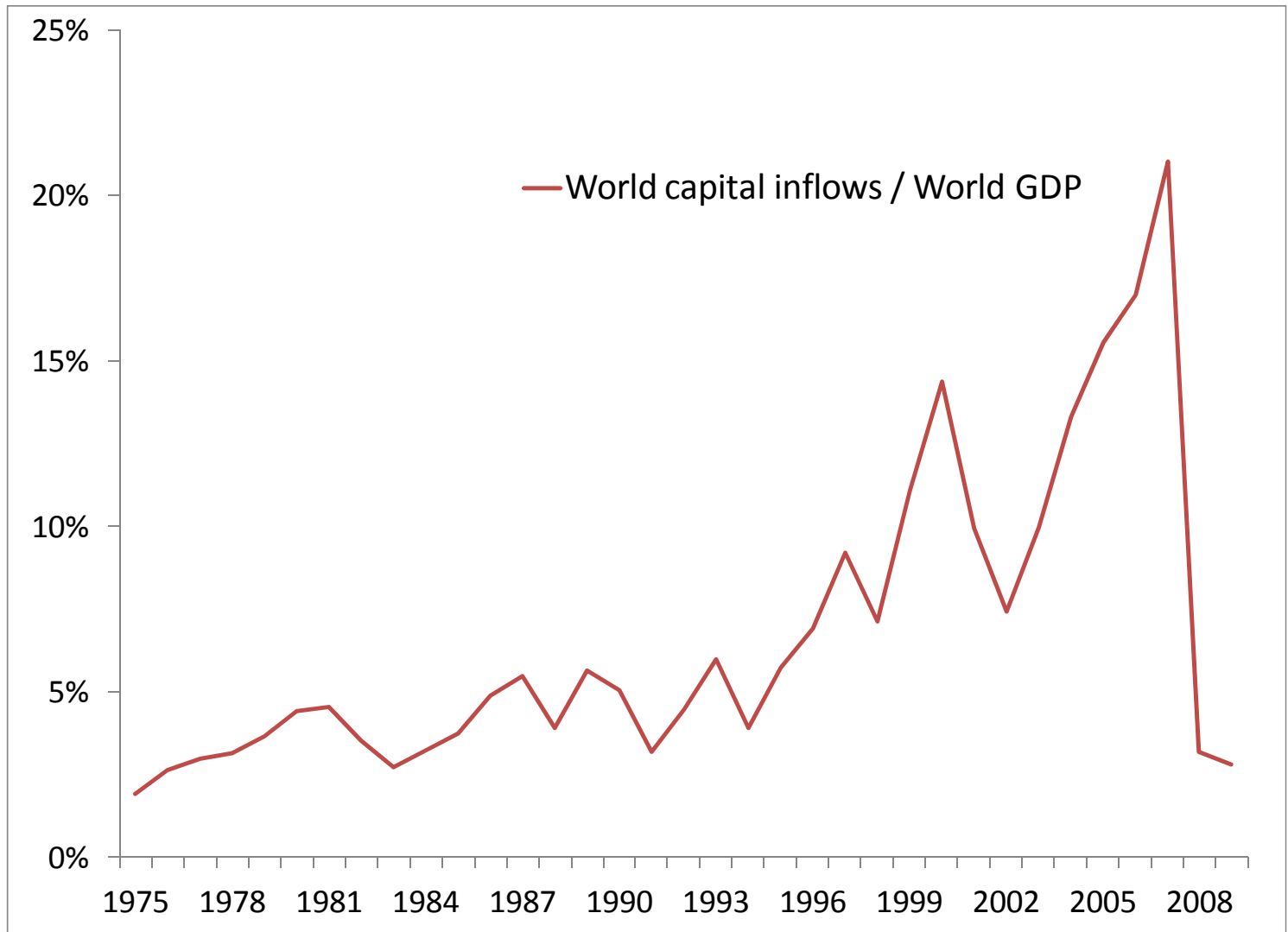

Note: sum of gross capital inflows across the world's countries, as a ratio of world GDP. Source: Lane and Milesi-Ferretti, EWN II database, and IMF, Balance of Payments Statistics. 
Figure 2. Financial deepening, advanced economies

Ratio of total financial assets to GDP

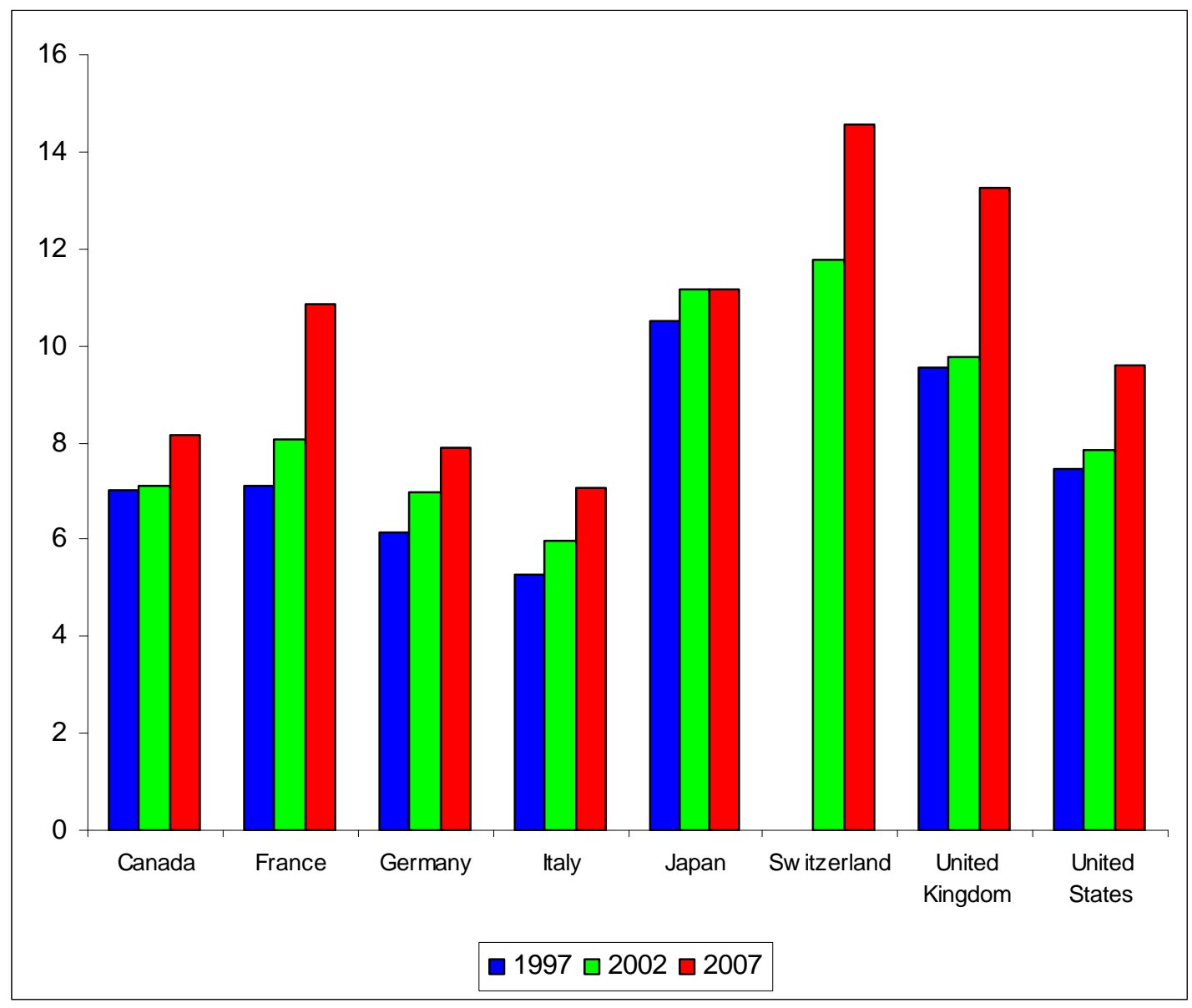

Source: Financial Accounts Statistics, OECD and Eurostat. 
Figure 3. Evolution of home bias, 2004-2007

Change in the ratio of external financial assets to total financial assets, annual rate
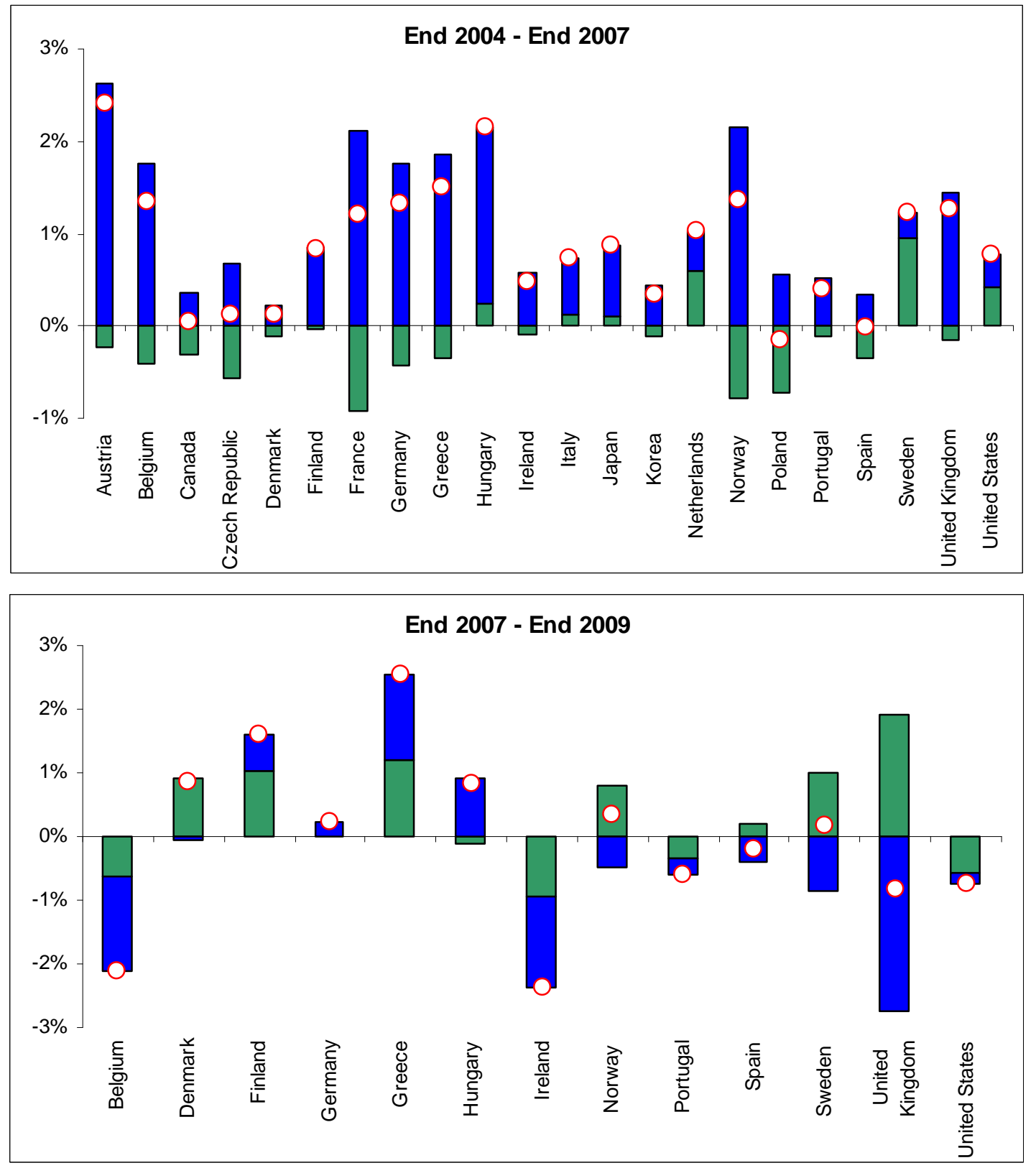

$\square$ Due to changes in asset prices $\square$ Due to acquisition of assets $\bigcirc$ Change in ratio

Note: the chart decomposes the average annual change in the ratio of external financial assets $(E A)$ to total financial assets (FA). The component due to the acquisition of assets (capital flows) is calculated as the change in the ratio that would occur if capital flows were the only driver: $\left[\left(E A_{t-i}+\right.\right.$ Flows $\left._{-} E A_{t-i ; t}\right) /\left(F A_{t-i}+\right.$ Flows $\left.\left._{-} F A_{t-i ; t}\right)-E A_{t-i} / F A_{t-i}\right](1 / i)$, where Flows $E A_{t-i ; t}$ ( Flows $\_F A_{t-i ; t}$ ) is total net purchases of external assets (total financial assets) between year $t-i$ and year $t$. The component due to changes in asset prices is the residual. 
Figure 4. Measures of capital mobility
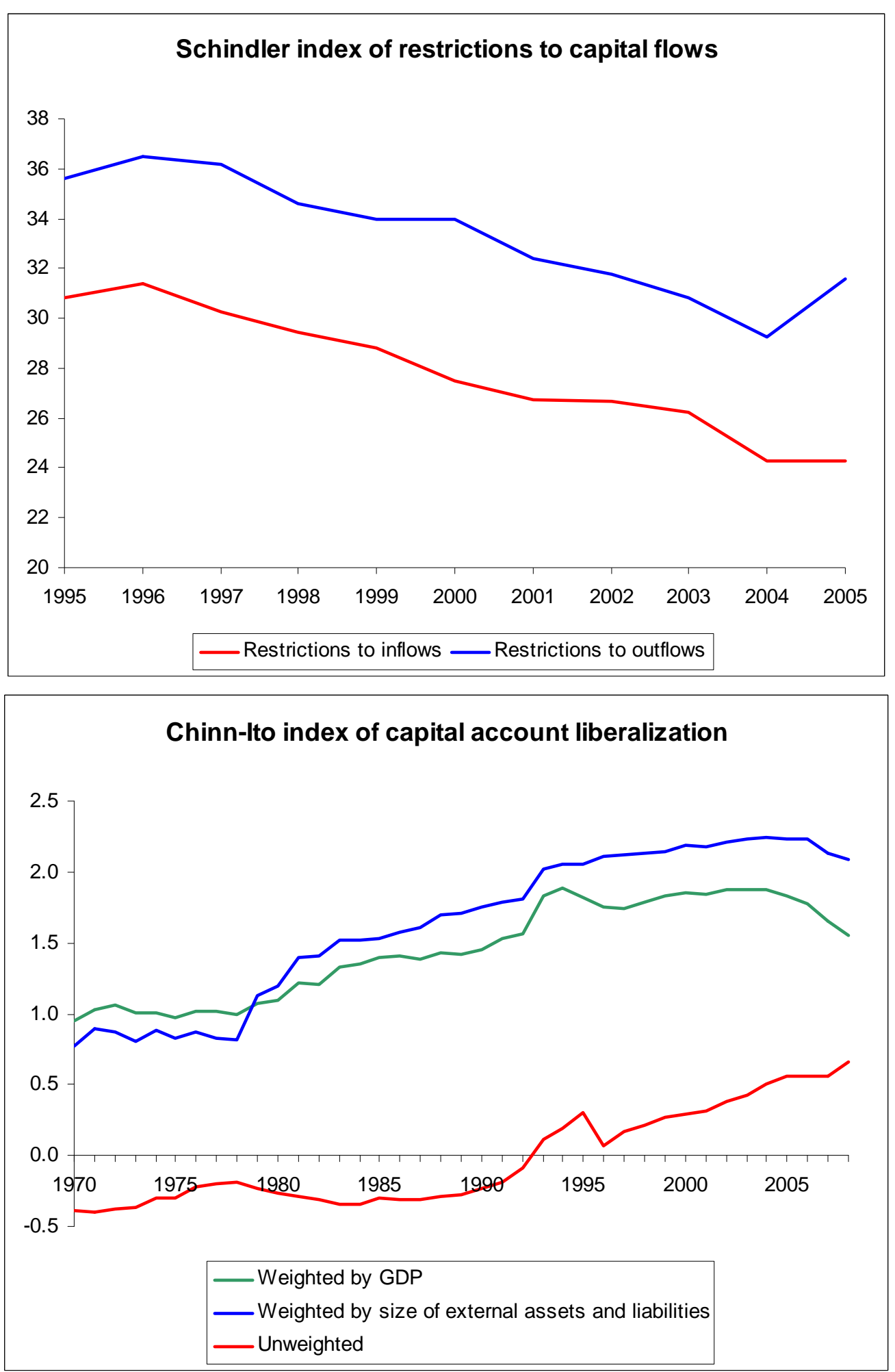

Sources: Chinn and Ito (2008), Schindler (2009). 
Figure 5. Cross border bank lending

Holdings at year-end, percent of world GDP.
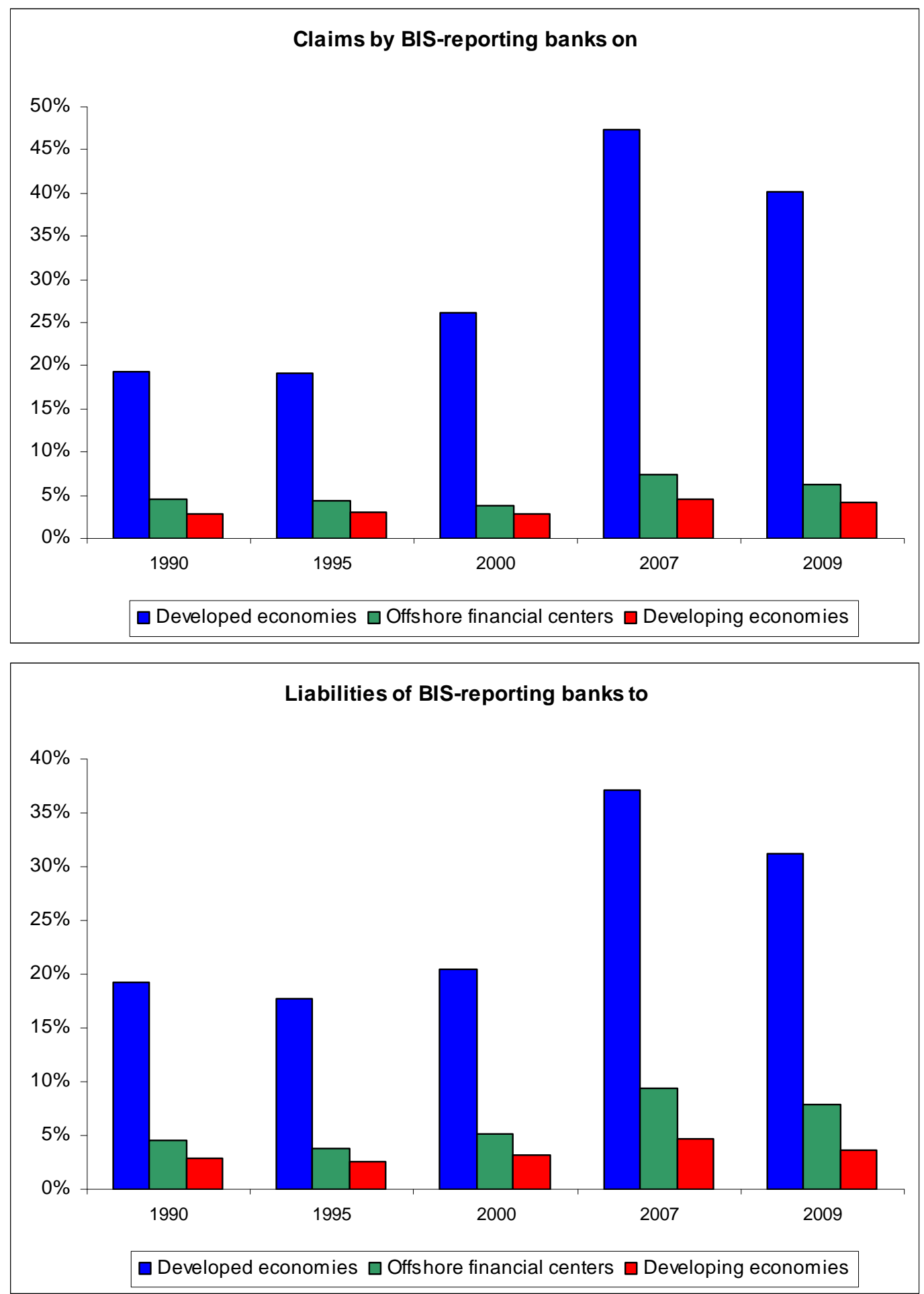

Source: BIS locational banking statistics. 
Figure 6: Role of banks in capital flows

USD billion, annualized rates

Advanced economies, gross outflows

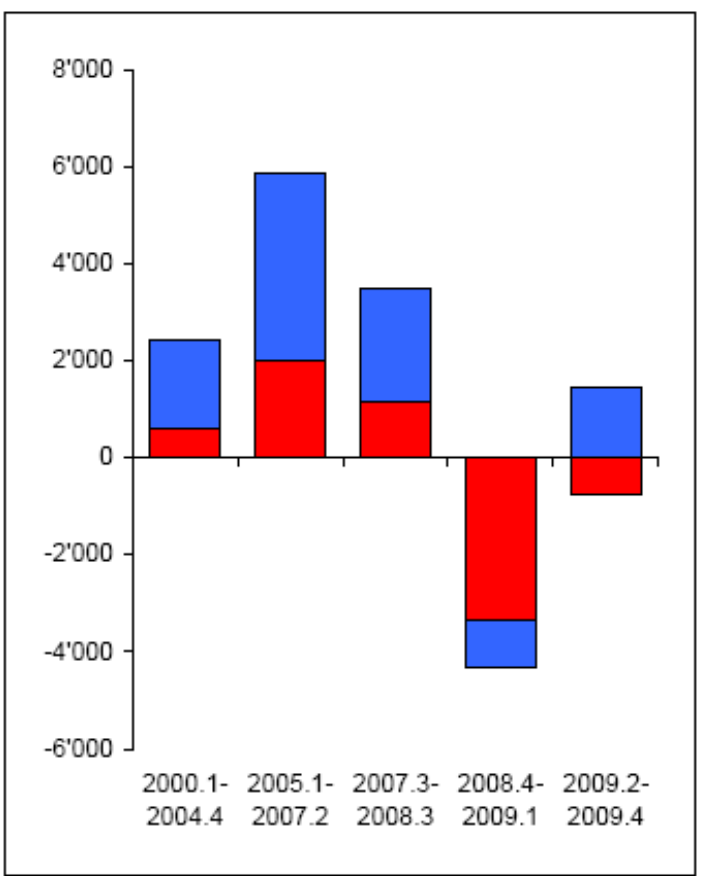

Emerging markets, gross outflows

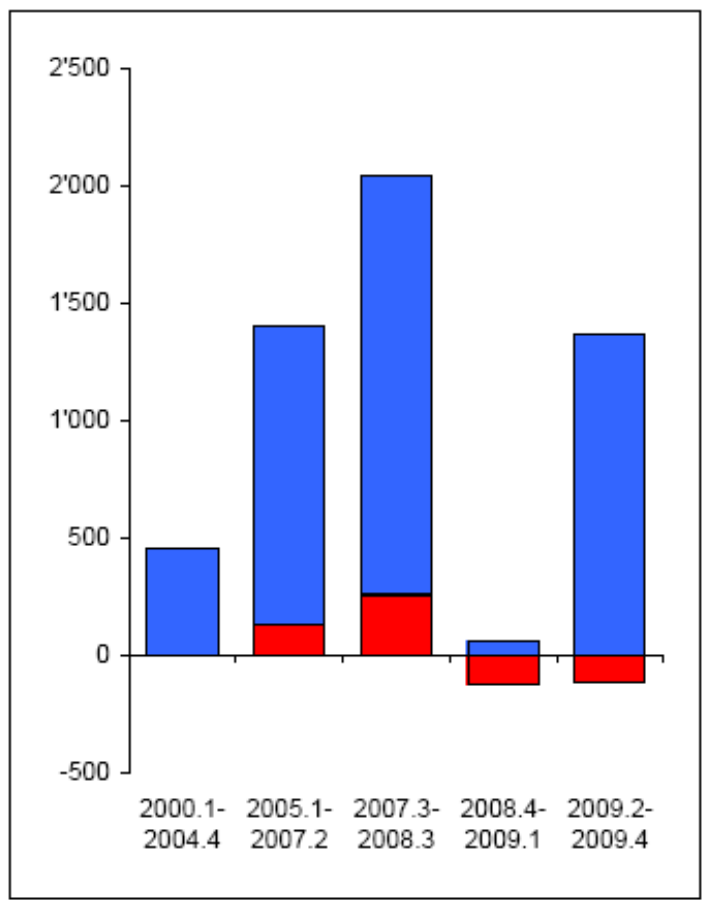

Danking flows
Advanced economies, gross inflows

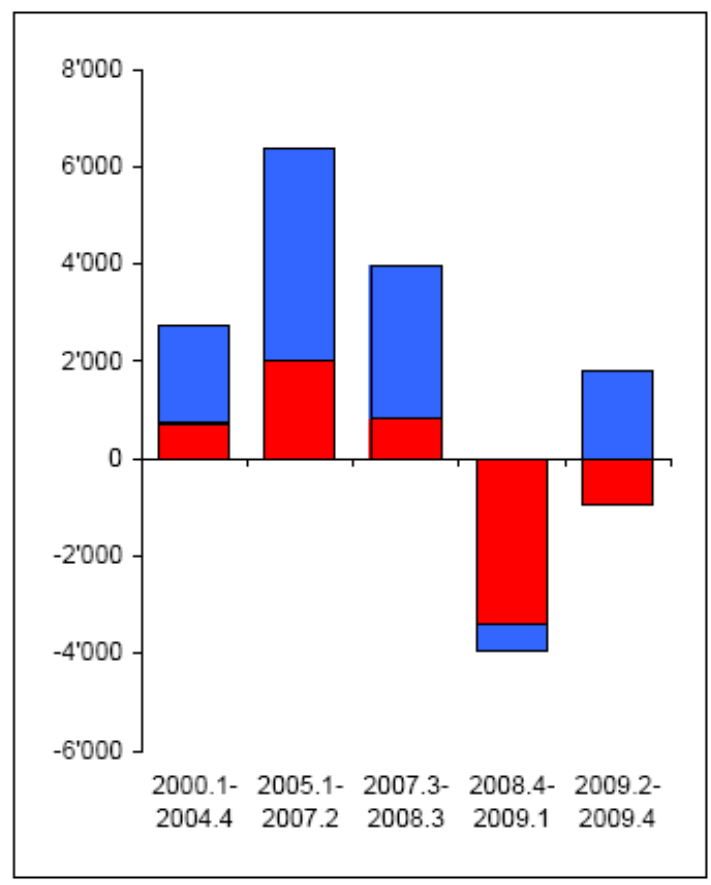

Emerging markets, gross inflows

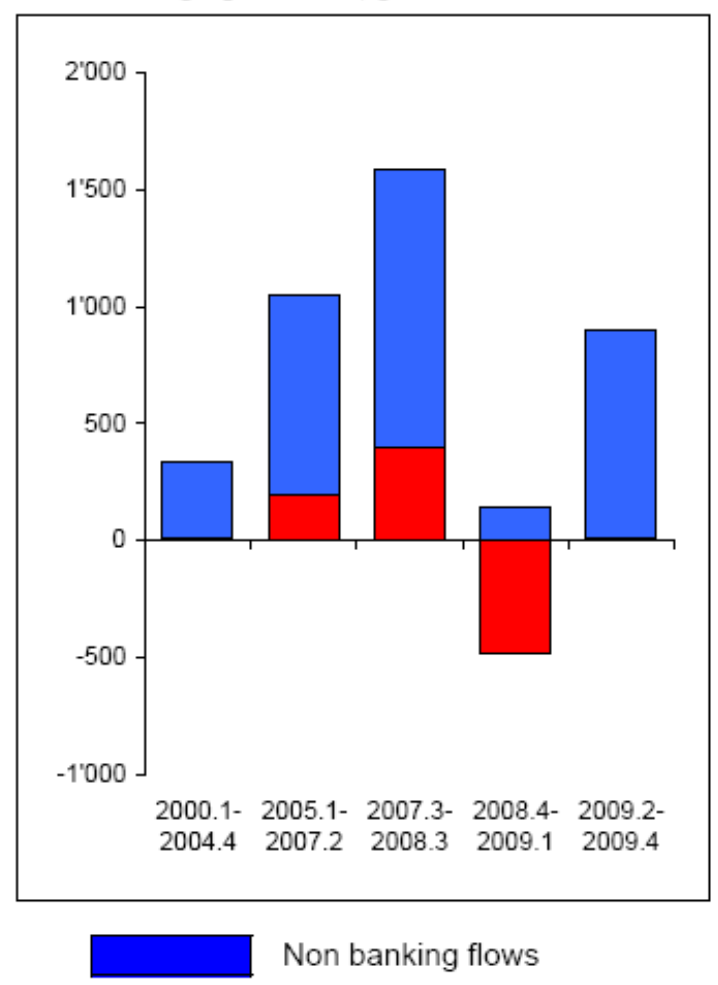

Source: IMF, Balance of Payments Statistics, authors' calculations. 
Figure 7: International bank integration
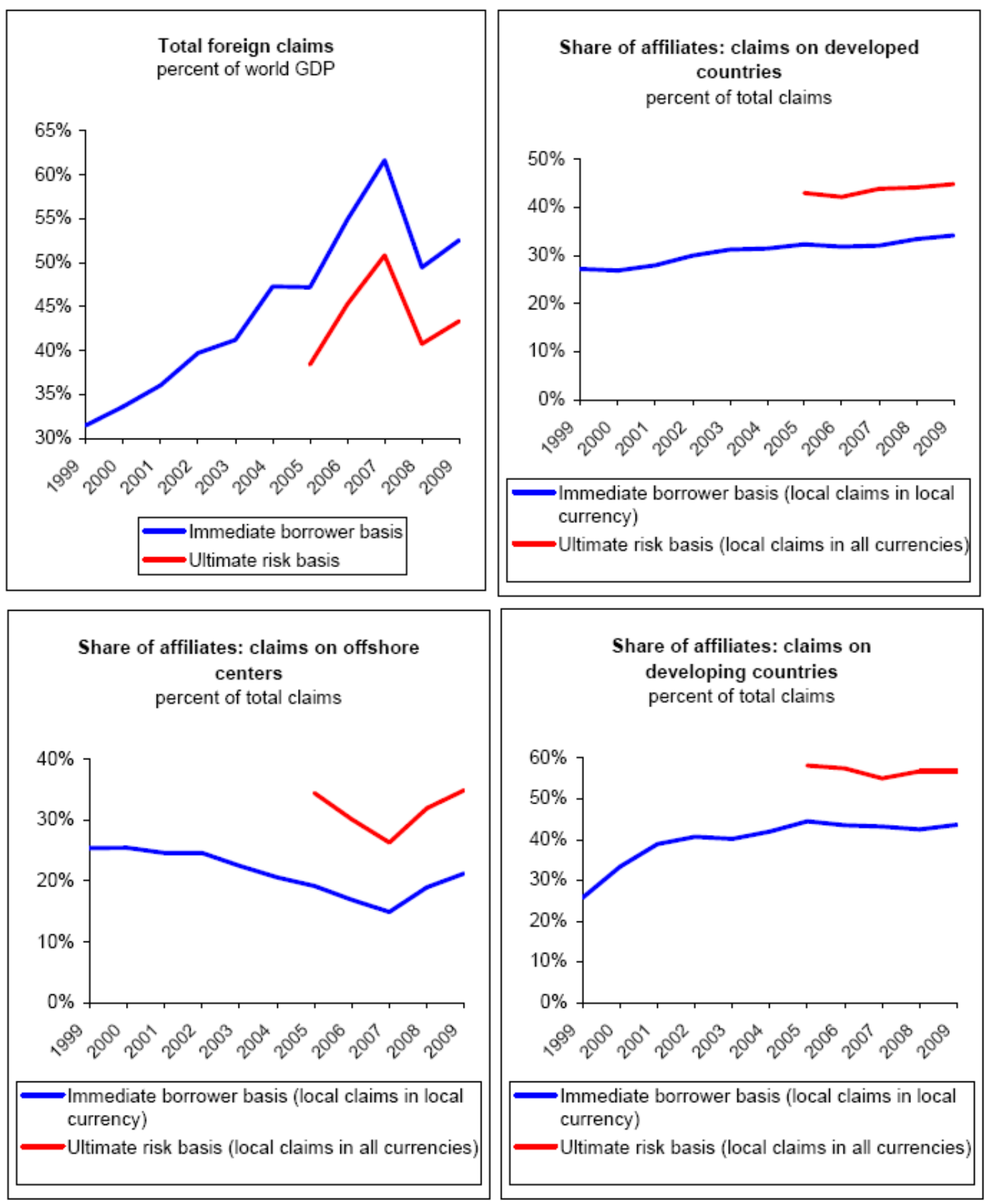

Source: BIS consolidated banking statistics. International bank exposures (foreign claims) takes the form of A) cross-border claims, B) claims through local affiliates in foreign currency and C) claims through local affiliates in local currency. The data on the "immediate borrower" basis split "international claims" $(A+B$ and $C)$ but do not include cross-border claims separately. The data on the "ultimate risk" basis distinguish between cross border claims and claims through local affiliates in all currencies $(B+C)$, but start only in 2005 and cover a narrower set of banks. 
Figure 8: Capital flows, advanced economies and emerging markets

US dollar billion

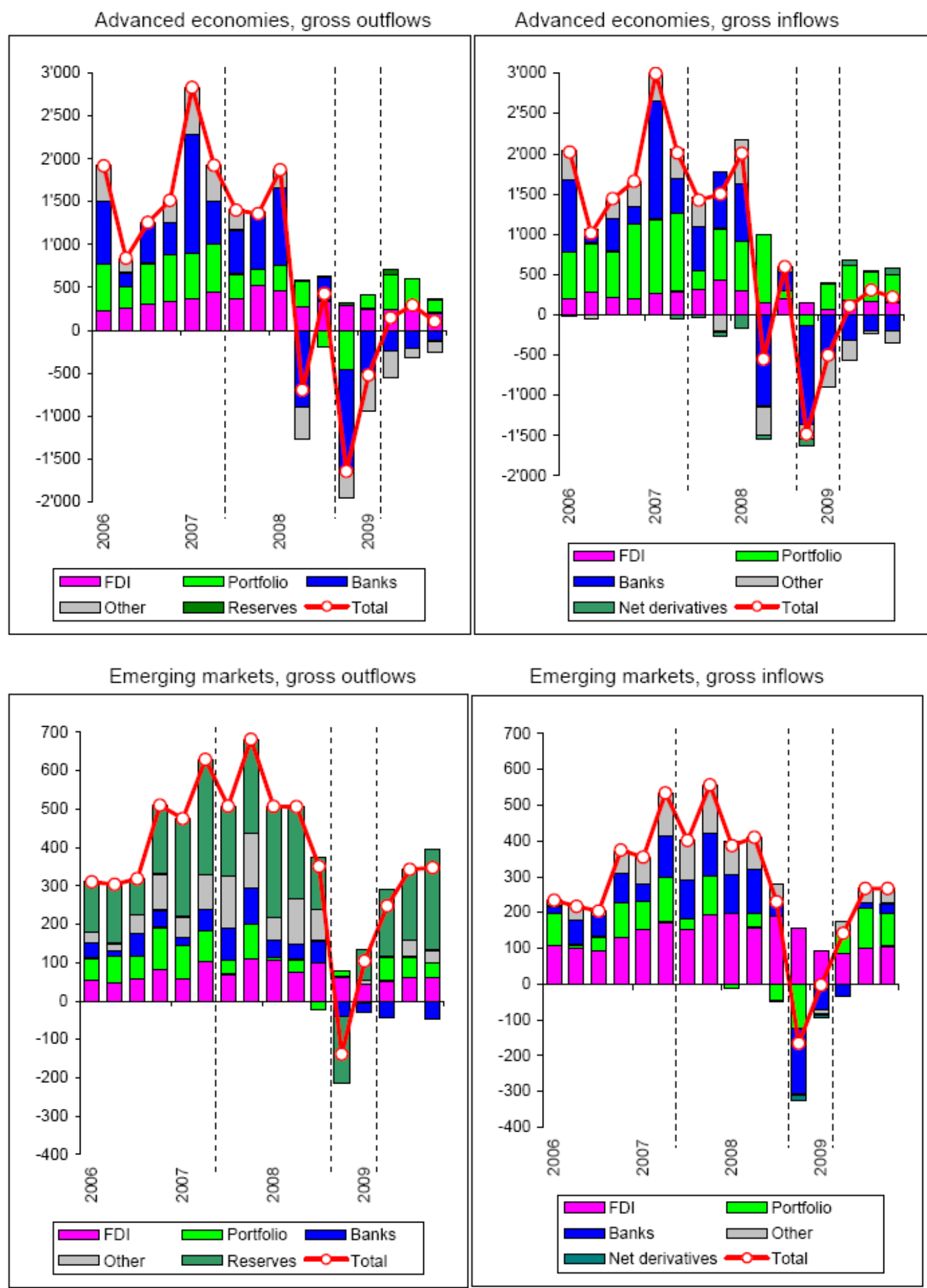

Source: IMF, Balance of Payments Statistics, authors' calculations. 
Figure 9: Geographical breakdown of capital flows, advanced economies US dollar billion

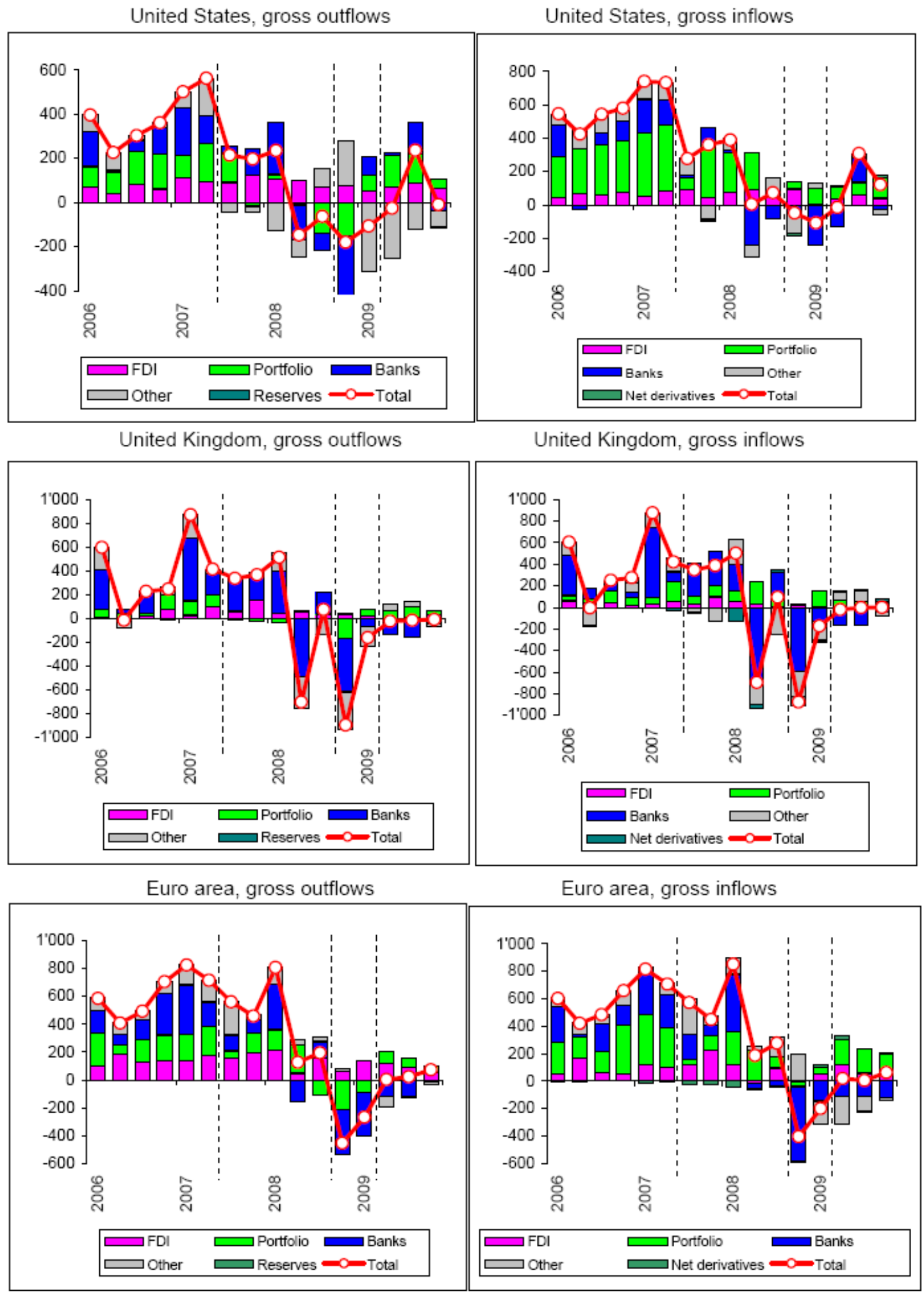

Source: IMF, Balance of Payments Statistics, authors' calculations. 
Figure 10: Geographical breakdown of capital flows, emerging markets US dollar billion

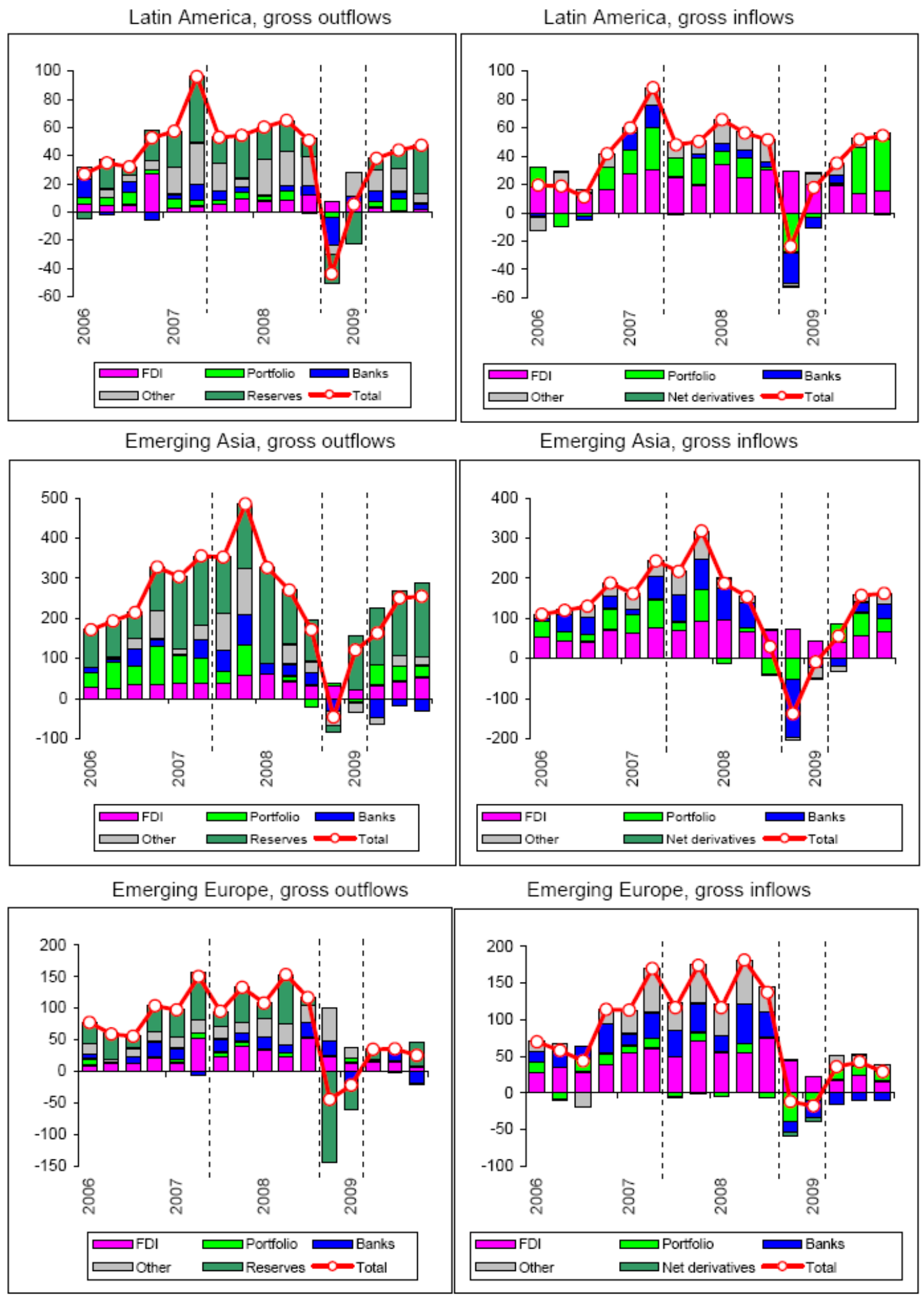

Source: IMF, Balance of Payments Statistics, authors' calculations. 